\title{
Palaeoclimate Research in Villars Cave (Dordogne, SW-France)
}

\author{
Dominique Genty ${ }^{1}$
}

\begin{abstract}
:
Genty D. 2008. Palaeoclimate Research in Villars Cave (Dordogne, SW-France). International Journal of Speleology, 37 (3), $173-191$. Bologna (Italy). ISSN 0392-6672.

Villars Cave is a typical shallow cave from South-West France $\left(45.44^{\circ} \mathrm{N} ; 0.78^{\circ} \mathrm{E} ; 175 \mathrm{~m}\right.$ asl $)$ that has provided several speleothem palaeoclimatic records such as the millennial scale variability of the Last Glacial period and the Last Deglaciation. Monitoring the Villars cave environment over a 13-year period has helped in the understanding of the stable isotopic speleothem content and in the hydrology. For example, it was demonstrated that most of the calcite $\mathrm{CaCO}_{3}$ carbon comes from the soil $\mathrm{CO}_{2}$, which explains the sensitivity of the $\delta^{13} \mathrm{C}$ to any vegetation and climatic changes. Drip rate monitoring, carried out under four stalactites from the lower and upper galleries, has shown a well marked seasonality of the seepage water with high flow rates during winter and spring. A time delay of about two months is observed between the water excess (estimated from outside meteorological stations) and the drip rate in the cave. A great heterogeneity in the flow rate amplitude variations and in the annual quantity of water between two nearby stalactites is observed, confirming the complexity of the micro-fissure network system in the unsaturated zone. At a daily scale, the air pressure and drip rates are anti-correlated probably because of pressure stress on the fissure network. Cave air $\mathrm{CO}_{2}$ concentration follows soil $\mathrm{CO}_{2}$ production and is correlated with its $\delta^{13} \mathrm{C}$ content. Since the beginning of the monitoring, the cave air temperature, in both lower and upper galleries, displays a warming trend of $\sim+0.4^{\circ} \mathrm{C} \pm 0.1 / 10 \mathrm{yrs}$. This might be the consequence of the outside temperature increase that reaches the Villars Cave galleries through thermal wave conduction. Chemistry monitoring over a few years has shown that the seepage water of the lower gallery stations is significantly more concentrated in trace and minor elements (i.e. $\mathrm{Sr}, \mathrm{Mg}, \mathrm{Ba}, \mathrm{U}$ ) than the upper stations, probably due to the $10-20 \mathrm{~m}$ depth difference between these galleries, which implies a different seepage pathway and different water/rock interaction durations. There is also, in the elemental concentration (i.e. [Ca]), a seasonal signal which causes variation in the speleothem growth rates. Modern calcite deposit experiments conducted for several years have permitted the calculation of vertical growth rates, which are extremely high in Villars (i.e. 1.0 to $1.75 \mathrm{~mm} /$ $\mathrm{yr}$ ). Pollen filter experiments in the cave have demonstrated that most of the pollen grain found in the cave comes from the air and not from the water. The specificity of the Villars Cave records is that the climatic variations were well recorded in the calcite $\delta^{13} \mathrm{C}$ whereas the $\delta^{18} \mathrm{O}$ is usually used in such studies. Overall, these results are helpful for the interpretation of speleothem records for palaeoclimatic reconstructions, but more work is needed, especially numerical modelling of the temperature, chemistry and hydrology.
\end{abstract}

Keywords: Stalagmite; speleothem; cave monitoring; palaeoclimate; cave geochemistry

Received 4 August 2008; Revised 6 August 2008; Accepted 4 September 2008

\section{INTRODUCTION}

\section{The Discovery}

It was at the end of a cold day in December 1953 that several cavers, members of the Spéléo-Club of Périgueux (SW-France), who were exploring the Cluzeau massif (named for a small nearby village), discovered Villars Cave. Since then, many explorations have confirmed that Villars Cave is one of the biggest in the Dordogne area with more than $10 \mathrm{~km}$ of galleries (Fig. 1 and 2) and among the richest in stalactite and stalagmite deposits (Fig. 3). In 1956, cave bear claw marks were discovered in the wall, sometimes covered by calcite deposits; this persuaded explorers to

1 LSCE, UMR CEA/CNRS/UVSQ 1572, L'Orme des Merisiers CEA Saclay, 91191 Gif/Yvette cedex (France),

dominique.genty@1sce.ipsl.fr look for traces of humans that might also have penetrated this cave. The first traces of paintings were found in 1957: an enigmatic black sign under thin layers of calcite. A few months later, after a more careful exploration of the "Salle des Cierges", near the present day exit, two paintings were found: a bison and a horse also made of black pigments. Just beneath them, a small passage almost closed off by a calcite wall was broken and the lucky cavers finally penetrated the painted part of the cave. Villars Cave became famous in France and many prehistorians have come to see the paintings. A tourist path, which winds through only a small part of the cave ( 200m), was constructed in 1959 by Armand Versaveau, the father of the present day owner of the cave, Hubert Versaveau, with the help of Robert De Joly and the cavers of the Spéléo-Club of Périgueux. 


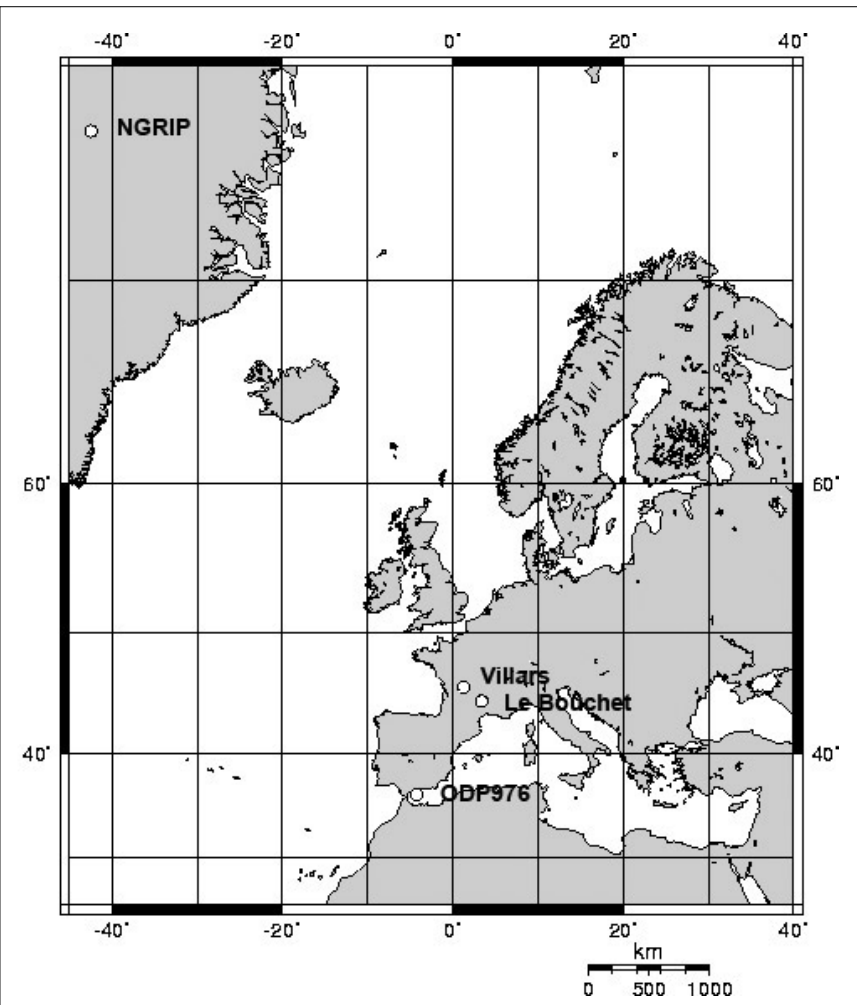

Fig. 1. Location of the Villars Cave $\left(45.44^{\circ} \mathrm{N} ; 0.78^{\circ} \mathrm{E} ; 175 \mathrm{~m}\right.$ asl)

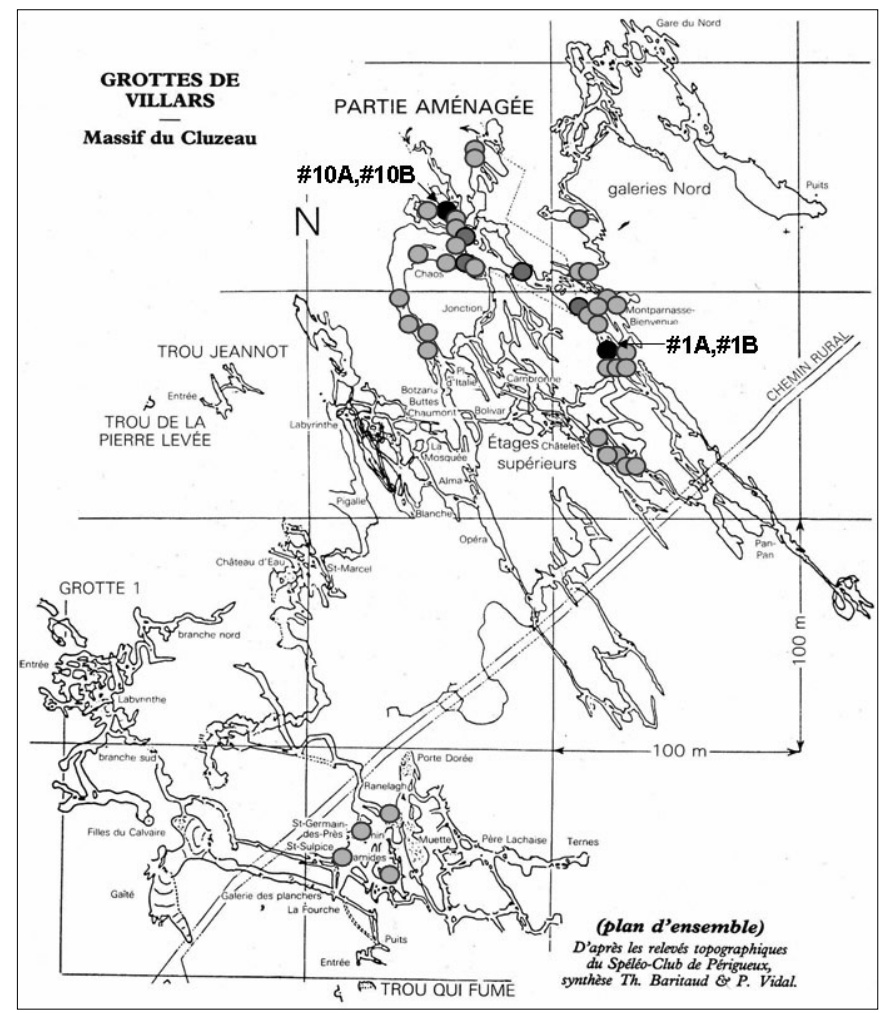

Fig. 2. Map of the Villars cave (Dordogne, SW-France; from Vidal and Baritaud, Spéléo Club de Périgueux). Light grey circles = stalagmite sampling (found broken); dark grey circles = flowstone sampling; black circles $=$ monitored stations $(\# 10 A, \# 10 B=$ upper galleries; $\# 1 \mathrm{~A}$, $\# 1 \mathrm{~B}=$ lower galleries).

\section{Prehistoric remains}

Besides the exploration, the primary interest of Villars Cave has been the paintings and the prehistoric remains found there (Delluc \& Delluc, 1974; Glory \& Pierret, 1960). The paintings were made directly on the rock or on a former layer of calcite, which constituted a very regular and smooth surface. The old age of the paintings was firstly demonstrated by the calcite deposits that cover them and by the stalactites that grew in front of some of them: in order to trace a painting of a small black animal, A. Glory, the prehistorian that studied these paintings, had to break a $25 \mathrm{~cm}$ long stalactite that had grown in front of it (!). The most famous painting is the "Cheval Bleu" (blue horse) that is painted alongside other horses in the "Rotonde des Chevaux". This painting appears slightly blue because of the light diffraction of manganese pigment through the calcite layer. The apparent "colour" depends also on the humidity of the wall. Other paintings represent bison, like the wonderful one in the "Salle des Cierges" almost entirely covered by a thick layer of calcite (Fig. 3 ), ibex or even one of the rare human figures found in prehistoric paintings, such as the human facing a bison just at the entrance. Several enigmatic signs have also been found, such as crosses and spots. The paintings were made with manganese oxides and can not be directly dated. According to their artistic style (Style III and IV - Leroi-Gourhand), they date from the end of the Lower Magdalenian. Recently, we did one ${ }^{14} \mathrm{C}$ AMS dating of a small piece of burned tooth found below the stalagmites of the "Salle des Peintures", which dates this hearth at 19500 years cal BP +-650 $(2 \mathrm{~s})$. It is possible that the paintings have a similar age.

\section{Cave environment and speleothems}

But the most important part of Villars Cave does not have prehistoric remains, and it is likely that prehistoric men did not go too far into the cave, especially in the lower galleries. The small entrances and long galleries situated at a relatively shallow depth in fractured limestone constituted a very favourable environment for the development of speleothems. In 1993, we started to study Villars Cave for palaeoclimate reconstructions, monitoring the cave environment by sampling seepage water for stable isotopes and geochemistry and analysing speleothems. Villars Cave is located about $200 \mathrm{~km}$ from the Atlantic Ocean, at a temperate latitude, and is thus ideally situated to record the impact of any changes in the Gulf Stream, the North Atlantic Oscillation, and to a lesser degree, the extension of the northern continent ice caps. Several studies have been conducted in Villars Cave on various subjects, the first ones were more dedicated to the study of the present day cave environment, while, more recent palaeoclimatic reconstructions using stable isotopes of stalagmites have been published. Information about the modern environment of Villars Cave can be find in the following studies: speleothem growth laminae and growth rates (Baker et al., 1998; Genty et al., 1997); preservation of cave environment (Baker \& Genty, 1998); water fluorescence (Baker \& Genty, 1999; Baker et al., 2000); bomb- ${ }^{14} \mathrm{C}$ recorded in modern stalagmites (Genty \& Massault, 1997); carbon transfer dynamics from the soil to the speleothem (Genty et al., 2001a; Genty \& Massault, 1999); water chemistry (Genty et al., 2001b); macroscopical fluid inclusion analysis (Genty et al., 2002); pollen sources (Genty et al., 2001c). The Villars stalagmites have recorded climate changes of the 


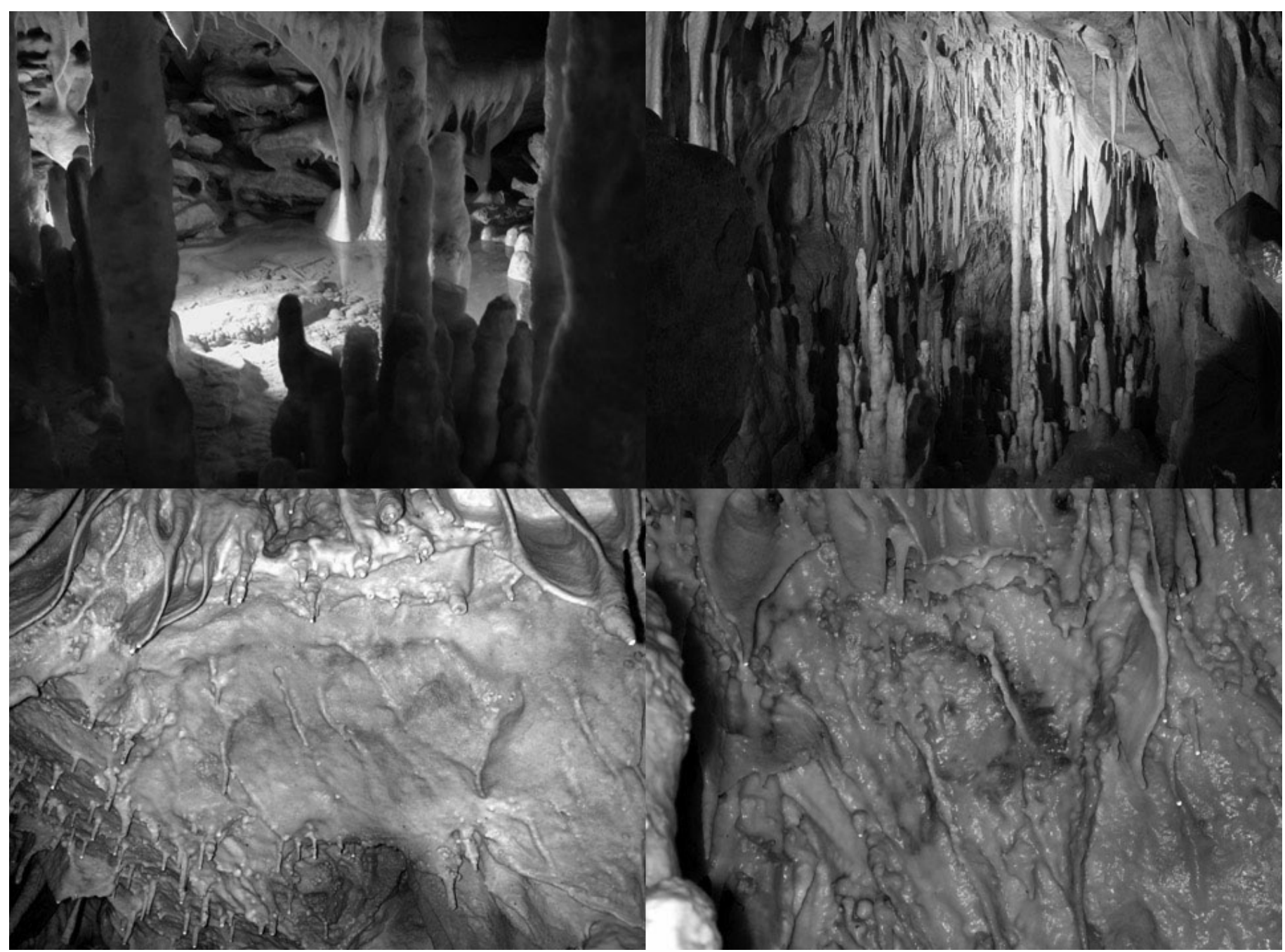

Fig. 3. Top left: A small gour in the Villars cave; top right : Stalagmites from the "Salle des Cierges"; bottom left : "Le Cheval Bleu" (Blue Horse) - Manganese painting covered by a thin calcite layer; bottom right : a Bison covered by a calcite layer and by stalactites (Early Magdalenian paintings).

last deglaciation (Genty et al., 2006) and of the climatic oscillations of the last glacial period (Genty et al., 2003; Genty et al., 2005). Several unpublished results show that there are deposits (stalagmites and flowstones) from at least stages 5 and 7 which will contribute to an extension of the palaeoclimatic reconstructions of this area (Wainer et al., 2007). In addition to the purely palaeoclimate interest, the fact that Villars Cave is located in SW-France, close to famous archaeological sites where Neanderthal remains have been found (i.e. Le Moustier, La Ferrassie, La Chaise) is a key point to better understand the link between environmental changes and the evolution of human cultures.

In this article we have gathered environmental, hydrological, isotopic and geochemical data from Villars Cave in order to better understand the present day cave system, a necessary prerequisite for a paleoenvironment interpretation of speleothems, keeping in mind that there is still a lot of work to do (dye tests, modelling of the infiltration).

\section{GEOLOGICAL SETTINGS}

Villars Cave is situated in the north of the Dordogne department, less than $3 \mathrm{~km}$ south of the crystalline rocks of the Limousin $\left(45.44^{\circ} \mathrm{N} ; 0.78^{\circ} \mathrm{E} ; 175 \mathrm{~m}\right.$ asl; Fig. 4). Hills measuring $\sim 50 \mathrm{~m}$ in height (at about
$200 \mathrm{~m}$ asl), covered by oak and hornbeam forests, are much less pronounced than around the Vézère Valley (south-east part of the Dordogne area), resulting in a smoother landscape. The cave developed in a Middle Jurassic Oolithic limestone formation (Bajocian and Bathonian), whose thickness varies from 25 to 45 $\mathrm{m}$. The intricate galleries are generally small and muddy; they compose a complex network over $10 \mathrm{~km}$ long whose directions are controlled by the regional tectonics (SE-NW), like the St. Pardoux fault that constitutes the border between limestone and schists a few kilometres north of Villars (Fig. 2, 4 and 5). We do not know the exact age of the formation of the Villars cave, but it is likely that because the area had emerged since the end of the Cretaceous, the cave formed very early, during the Tertiary or early Quaternary, similar to most caves in the area (Fenelon, 1951).

Even though Villars Cave does not have huge vertical shafts, we can distinguish two different levels of galleries separated by $\sim 10-20 \mathrm{~m}$ (Fig. 6). The lowest galleries are occupied by clayey sediments which constitute the ancient river bed of the Trincou which stopped flowing into the cave about twenty years ago when drainage works were carried out in the fields in front of the cave. Water dissolution cupola can be observed in these galleries at a height of about 2 metres. 


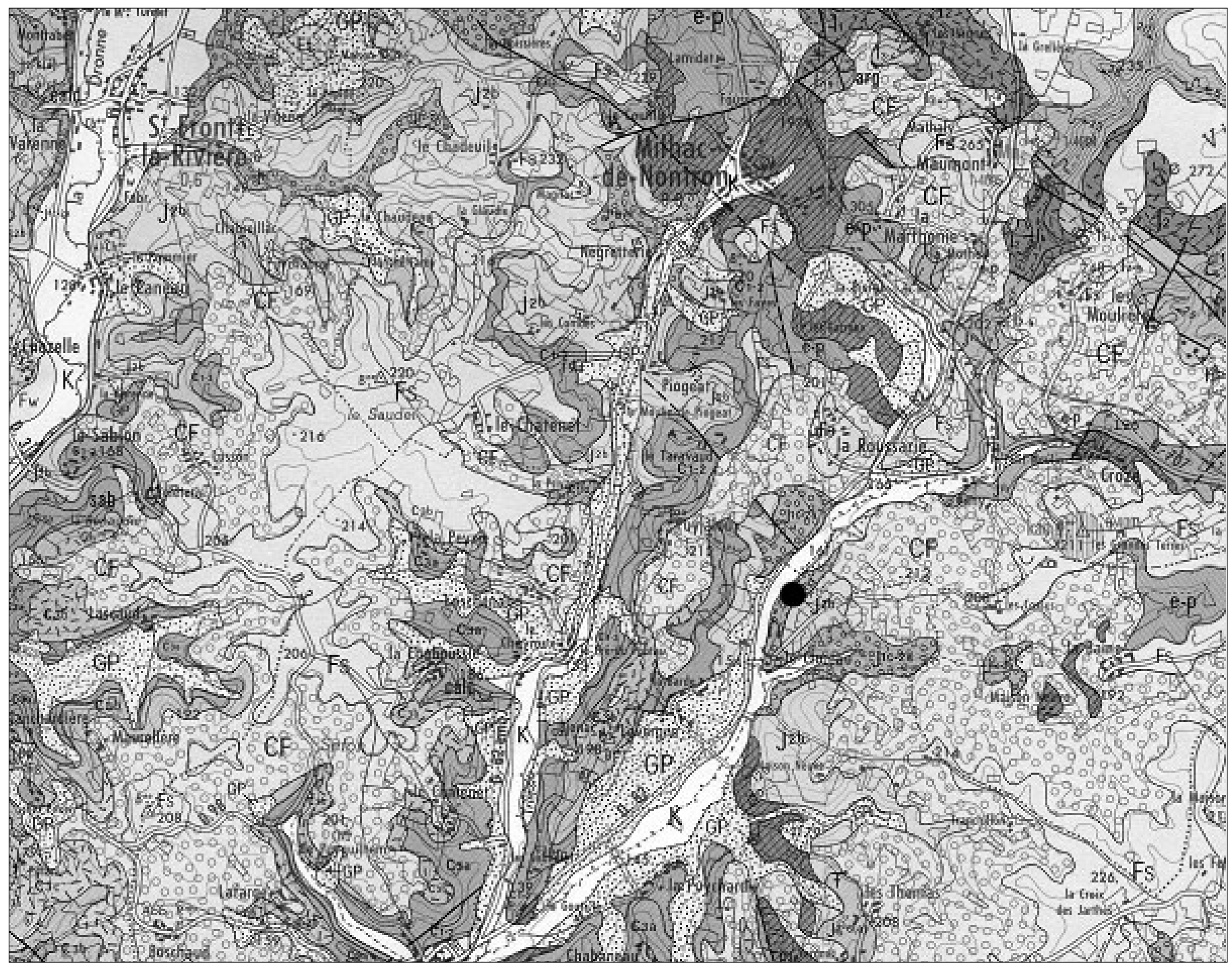

Fig. 4. Geological map of area around the Villars Cave (dot) - (C) : Cretaceous; (J) : Jurassic where the Villars Cave develops (dot); (L) : Lias; at the top right $(\varepsilon)$ : crystalline/meta-volcanic rocks ; from BRGM, Service Géologique National, Orléans, France; Thiviers Map XIX-33 1/50000.

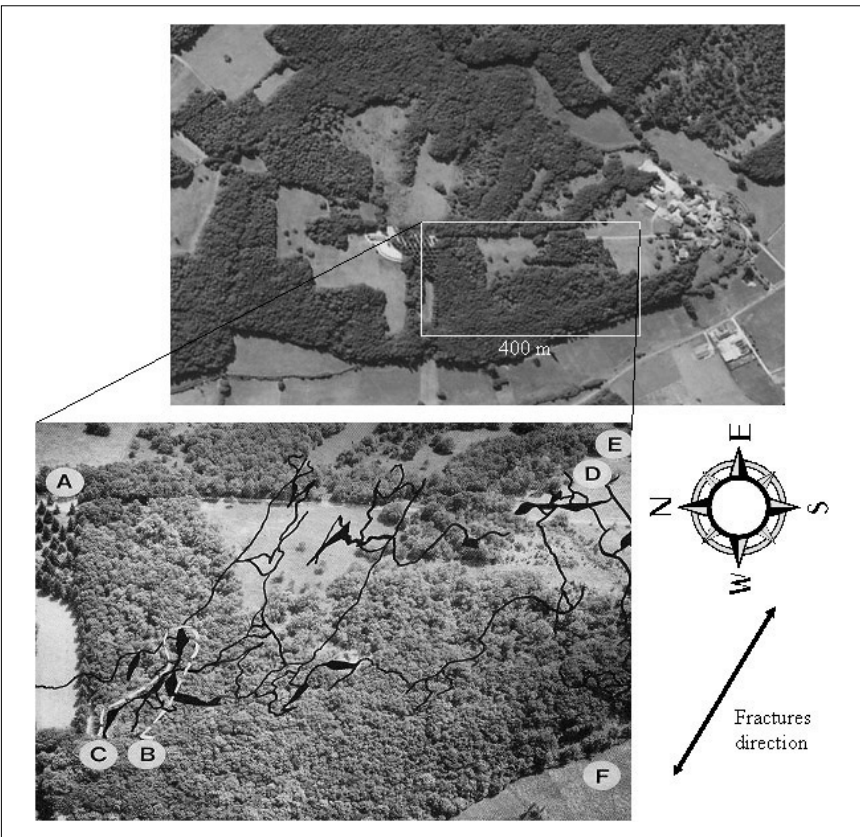

Fig. 5. Villars Cave site. Above : Aerial photo taken in Summer 2001 with "Le Cluzeau" Village at the right; below: superposition of the cave network with the vegetation cover : $B$ and $C$ : entrance and exit of the touristic path; $F, D, E$ : other small entrances; $A$ : tourist information center (from Vidal and Baritaud, Spéléo Club de Périgueux).
The Bajocian geological formation is relatively homogeneous and constituted by white limestone with oolites measuring around $0.5 \mathrm{~mm}$ in diameter, however, there are some places that have been recrystallized and vertical or sub-vertical very hard limestone planes $10-20 \mathrm{~cm}$ thick, made of oolites and iron calcite cement are common to observe. Isotopic measurements of a few limestone samples show typical values of marine limestone deposits: $\delta^{18} \mathrm{O} \sim-1.9 \% \pm 0.1$ and $\delta^{13} \mathrm{C} \sim-5.4 \%$ o 0.1 .

\section{HYDROLOGY, CLIMATE AND VEGETATION: MONITORING OF THE PRESENT DAY ENVIRONMENTAL CONDITIONS}

Because it contains prehistoric paintings, the cave environment was monitored early, in the sixties. Temperature measurements have shown that the lower galleries have a constant temperature $\left(11^{\circ} \mathrm{C}\right.$ \pm 0.1 ), while towards the painted chamber, near the exit, the temperature increases during the summer months and nearly reaches the external temperature (1 or $2{ }^{\circ} \mathrm{C}$ below) (P. Vidal measurements, French Culture Ministry in Delluc \& Delluc, 1974). This was likely the case before the preparation of the cave for tourists in 1959. This is the typical behaviour of a 


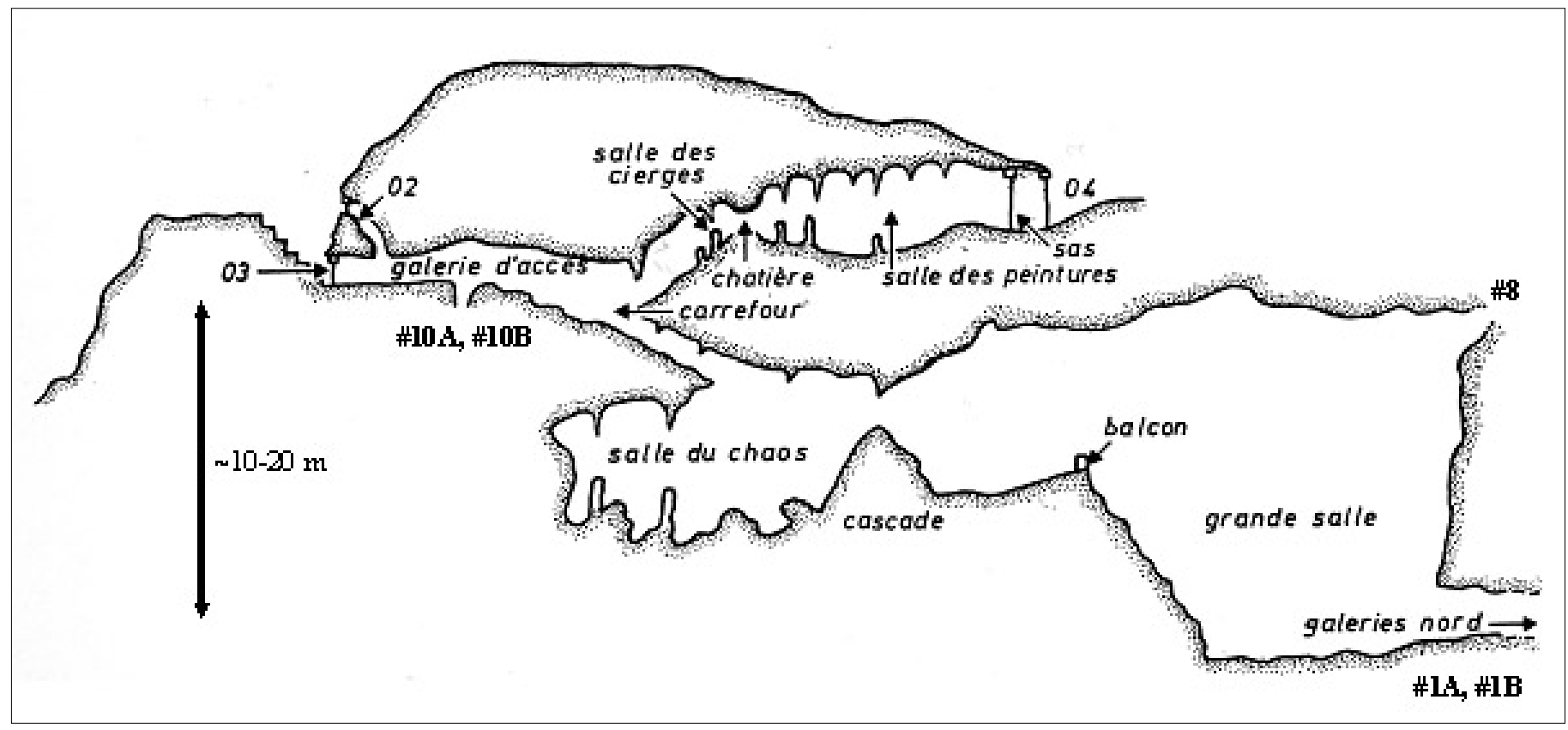

Fig. 6. Schematic cross section of the Villars Cave (from Delluc and Delluc, 1974).\#10A, \#10B monitoring stations of the upper galleries; \#1A, \#1B, monitoring stations of the lower galleries; \#8 : monitoring station on upper galleries on the wild part of the cave.

"descending" cave where most entrances are at the upper levels and no exits are located below.

Besides these first temperature measurements, whose aim was the protection of the prehistoric paintings, we started regular measurements of several environmental factors in 1993 in order to better understand the seepage water chemistry variations and their link with the climate outside the cave. Different places, under stalactites, were chosen for seepage water analyses: stable isotope measurements, chemistry and drip rate measurements. Temperature, air pressure, conductivity and $\mathrm{pH}$ were also measured more or less continuously. At the beginning of our study, up to ten stations were monitored in this way. We now sample seepage water at only four stations regularly (1-2 months), two in the upper galleries and two in the lower ones (Fig. 2 and 6). Automatic stations have done all other measurements since January 1997, with some gaps due to technical problems. We present here a synthesis of the most important results from this monitoring and its interest for the interpretation of speleothem palaeoclimatic records.

\section{CLIMATIC SETTING AROUND VILLARS CAVE}

The climate around Villars is typical temperate maritime, with mild winters (1984-2007 average JFM temperature $=6.5^{\circ} \mathrm{C}$ at the Nontron station about $15 \mathrm{~km}$ far from the Cave) and relatively cool summers (average JAS temperature $=18.7^{\circ} \mathrm{C}$ ). We have considered hydrological years (September to September) as it coincides with minimum water budget. Annual rainfall is $1023 \mathrm{~mm}$ for the $1984-2007$ period but displays a large variability $(1 \sigma=207 \mathrm{~mm})$, from very wet years like in $1988 / 89$ where $\mathrm{R}=1449 \mathrm{~mm}$ to very dry ones like 2005/06 where $\mathrm{R}=682 \mathrm{~mm}$ (Fig. 7 and 8). The rainfall seasonality is not well marked in the rainfall but rather in the temperature, however, it is interesting to note that the rainfall variability is higher during the spring and autumn months and lower in February and July
(Fig. 8). Mean external annual temperature between 1984 and 2007 is $12.2^{\circ} \mathrm{C}\left(1 \sigma=0.8^{\circ} \mathrm{C}\right)$ which is close to the present day cave temperature of the upper galleries $\left(12.5{ }^{\circ} \mathrm{C}\right.$ for the last ten years), but much higher than the temperature of the lower galleries $\left(11.5^{\circ} \mathrm{C}\right.$ for the last ten years, see discussion in the next sections).

An interesting feature of the Nontron data is that annual temperature has shown a warming trend since 1984 of about $0.9^{\circ} \mathrm{C} / 10 y e a r s$ and, within this trend, the 2003 temperature anomaly is remarkable (average temperature $=13.6{ }^{\circ} \mathrm{C}$ ) (Fig. 7 ).

\section{VEGETATION, POLLEN GRAINS AND AIR $\mathrm{CO}_{2}$ SOURCES}

\section{Vegetation and pollen}

The vegetation above the cave is composed of oak trees, hornbeam, hazelnut trees and mosses (Fig. 9). The brown soil is very thin $(0-20 \mathrm{~cm}$ thick) and this might explain why the tree roots penetrate far down into the epikarst rock formation through the limestone fractures. Roots are visible in the roof of the cave near the painted part at about $10 \mathrm{~m}$ below the surface (Fig. 9). Most of the cave galleries are situated under this forest, except the eastern part and a large portion of the southern section of the gallery network, called "Le Trou qui fume", which is nowadays under a grass field located near the owner's farm (Fig. 5). But vegetation density has changed a lot recently as evident on aerial pictures taken between 1950 and 2001 (Fig. 10). Like many other places in France, the forest has expanded since the beginning of the 20th century, especially after the First World War, and more intensively since the fifties due to the increased drift from the land. This is particularly visible in the Dordogne countryside post cards of the early 1900's, where hills are denuded and rock cliffs are very visible. It is likely that the impact of the vegetation development on the hydrology and on the isotopic composition of the seepage water is not 


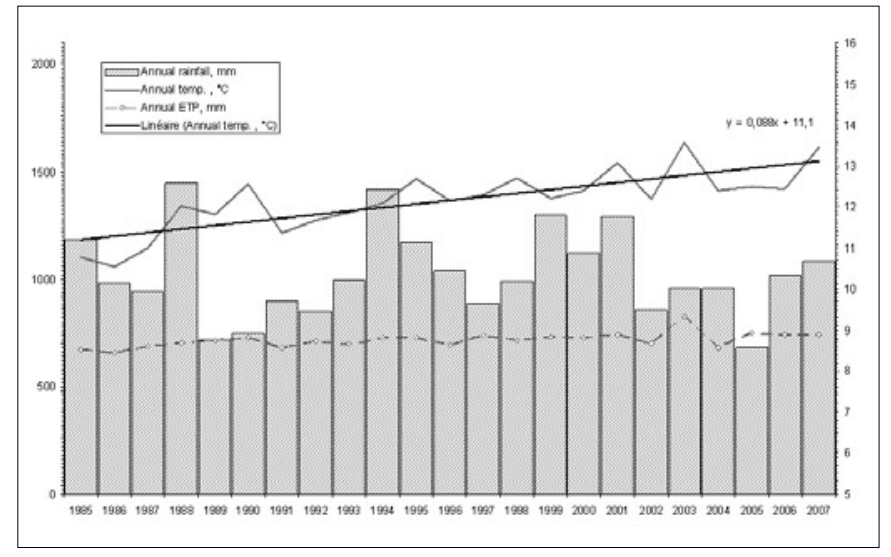

Fig. 7. Inter-annual rainfall and temperature changes near the Villars Cave between 1984 and 2007 (Nontron meteorological station, 15 $\mathrm{km}$ far from Villars). Averages from hydrological years (September $\rightarrow$ August). Note the temperature increase trend of about $0.9^{\circ} \mathrm{C} / 10$ years and the 2003 temperature anomaly.

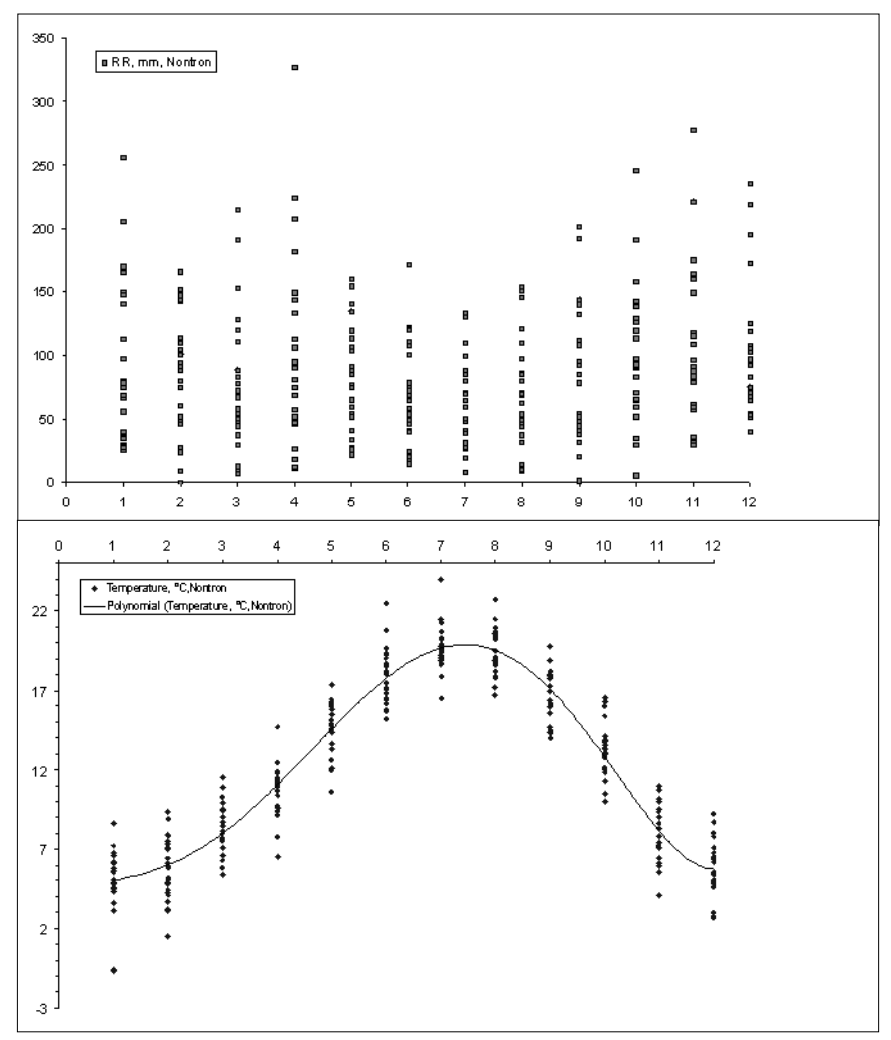

Fig. 8. top: Monthly rainfall variability between 1984 and 2007 at the Nontron station, $15 \mathrm{~km}$ far from the Villars Cave (Météo France data); bottom : monthly average temperature variability (numbers $=$ months).

negligible and it might explain the $\delta^{13} \mathrm{C}$ decrease that is observed in several modern stalagmites (Genty, 2003).

Because stalagmites may contain pollen grains and thus give palaeoecological information, we have made a two-years experiment in Villars Cave in order to check the pollen grain sources. Pollen traps $(5 \mu \mathrm{m}$ nylon filters) were placed under dripping stalactites, one year without any protection, the next year with a protection around the filter up to the cave roof all around the stalactite (Genty et al., 2001c). Results have shown that protected filters did not give any significant amount of grains despite the hundreds of litres of water that went through, while unprotected ones contained several dozens of grains; this

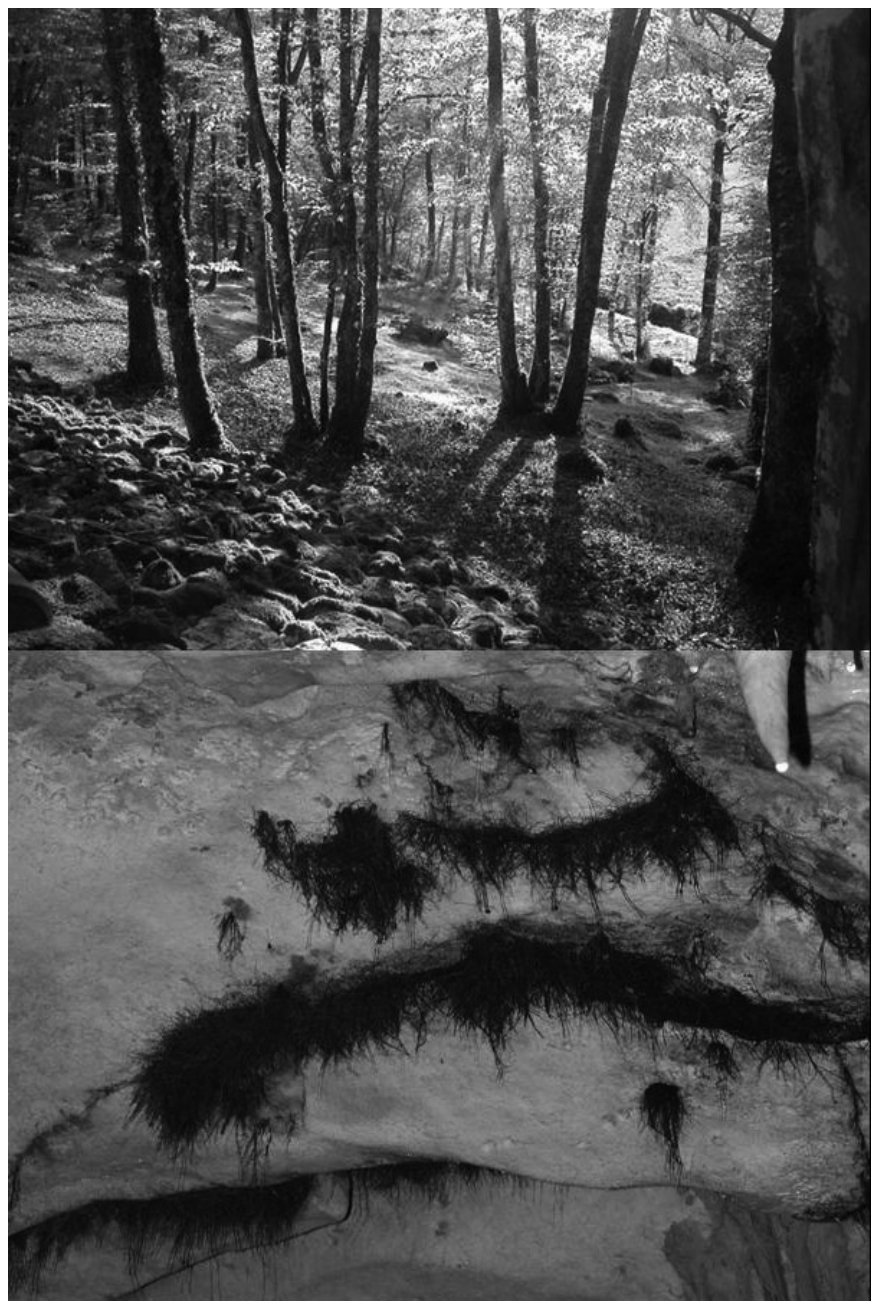

Fig. 9. top : Vegetation above the Villars Cave : oak trees, hornbeam, hazel trees and mosses; bottom: tree roots appearing in the ceiling of the Villars cave near the "Salle des Cierges" about $10 \mathrm{~m}$ below the surface.

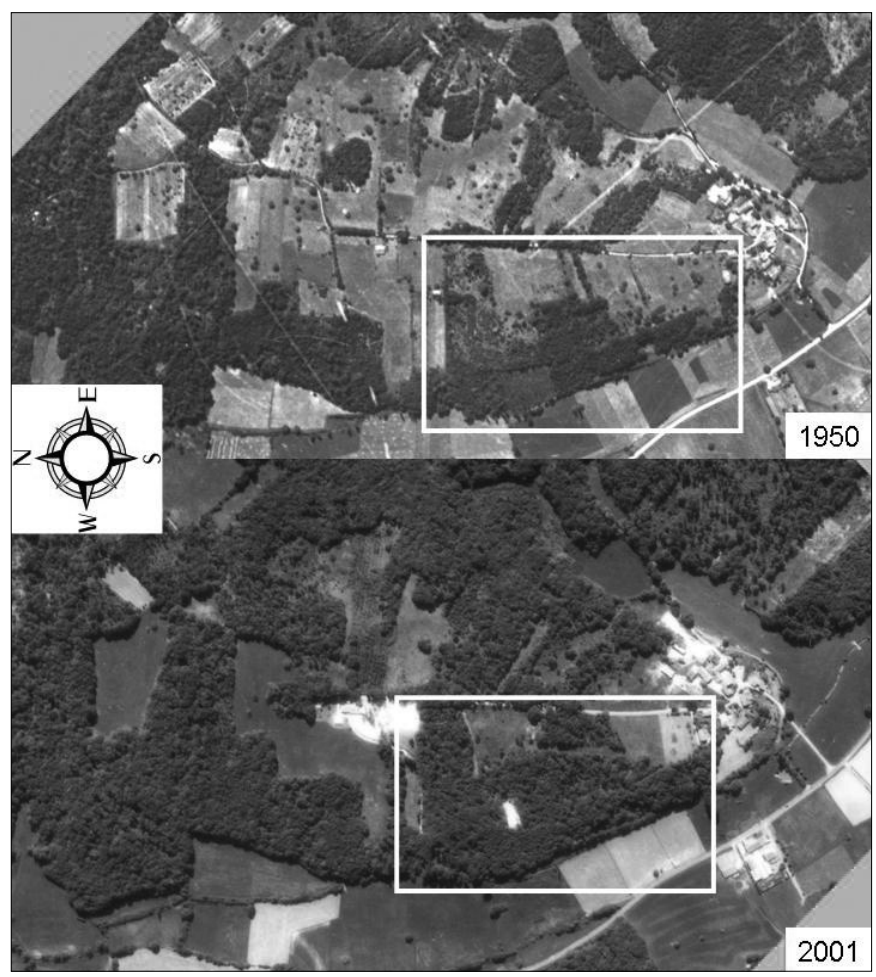

Fig. 10. Vegetation cover increase above the Villars Cave between 1950 (top) and 2001 (bottom) (IGN photos). Note the development of the vegetation above the cave area (white rectangle). 
demonstrates that, at least at these places, pollen is not brought by the seepage water but rather by the air, and likely by tourists that are numerous during the summer and by observed animals (dormice, bats). A natural airborne pollen grain source is less likely because cave entrances are closed by doors since the sixties. Mosses taken above the cave, in the forest, have shown a high percentage of tree pollen $(77 \%)$ and a large number of taxa (34) representative of the local vegetation: Carpinus (39\%), Pinus (16\%), Corylus (6.1\%), Quercus ped. (4.1\%), ferns (less than 1\%), Graminaceae (Poaceae: 10.2\%) and saprophyte fungal spores. This in situ experimentation permitted also to observe, besides pollen grains, a large number of micro debris which are constituted by organic matter particles larger than $5 \mu \mathrm{m}$ and by unidentified plant tissue remains less than $100 \mu \mathrm{m}$ long. Under the microscope, small opaque particles (less than $20 \mu \mathrm{m}$ long) were observed, composed of microcharcoals and/or inert organic matter (inertinite). More surprisingly, plant bristles and insect hairs were abundant, for example, a wing (125 $\mu \mathrm{m}$ long) and an insect leg were found. A few fresh water algae were also found in these traps. Like for the pollen grain, the micro debris were more abundant in the unprotected filters suggesting that they were also brought by the air.

\section{Cave air $\mathrm{CO}_{2}$ concentrations and stable isotopic composition}

The impact of the outside vegetation activity on the cave air $\mathrm{CO}_{2}$ can be seen in the concentration and isotopic measurements that are made at different places. $\mathrm{CO}_{2}$ concentrations vary from 1500 to 3000 ppm in the upper galleries (stations \#10A and $\# 10 B$ ) and from 4000 to $8000 \mathrm{ppm}$ in the lower galleries, near the stations \#1A and \#1B. Maximum concentrations usually occur during summer and autumn and minimum in winter, following the $\mathrm{CO}_{2}$ production in the soil above the cave as observed in other caves from South France (Bourges et al., 2001). The isotopic composition is closely correlated with the $\mathrm{CO}_{2}$ concentration and varies from -20.0 to $-23.6 \%$ demonstrating that the $\mathrm{CO}_{2}$ comes mostly from the vegetation activity in the soil and epikarst zone above the cave (Fig. 11).

Radiocarbon activity measurements have been made on the seepage water dissolved inorganic carbon (DIC, mainly $\mathrm{HCO}_{3}$ ) and on the cave air $\mathrm{CO}_{2}$ of Villars Cave. Measured ${ }^{14} \mathrm{C}$ activity on the water DIC is about 20 pMC lower than the ${ }^{14} \mathrm{C}$ activity of the atmosphere outside the cave (average water $\mathrm{HCO}_{3}=93.3 \mathrm{pMC}$ and $114 \mathrm{pMC}$ for the atmosphere, 1996-1997 AD). This is likely due to the dead carbon brought in by the seepage water during limestone dissolution; it is close to the dead carbon values obtained on modern stalagmites in this area (15 $\pm 5 \%$; Genty et al. 1997, 1999 and unpublished data). The cave air $\mathrm{CO}_{2}{ }^{14} \mathrm{C}$ activity is also slightly lower than the outside ${ }^{14} \mathrm{C}$ activity (93.1 pMC against 112 pMC, 1999 AD) which can be explained by a small contribution of the dead carbon to the cave air $\mathrm{CO}_{2}$ due to the degassing during calcite precipitation and by the contribution of old organic matter degradation in the soil.

\section{HYDROLOGY}

\section{River bed}

As already mentioned, a SE-NW fault separates the Cretaceous and Jurassic limestone deposits from the impermeable schists a few kilometres north of the cave. Most rivers flowing from this old impermeable massif go, in fact, northward via underground conduits. This is the case of the two streams that feed the "Trincou", the small river that flows near Villars Cave (close to "Le Cluzeau" on the map, Fig. 4). Water fluorescence colorations confirmed that these streams resurface in the Dronne River at Chazelle, a small village 5 $\mathrm{km}$ E-NE of Villars Cave (left border of the map). An important characteristic of the local hydrology is that water streams do not take the dry valley directions but rather take the faults through underground passages. But, during wet periods (winter and early spring), these passages can not absorb all the water and, consequently, the Trincou appeared in the valley and flowed in the lower galleries of the cave during flooding periods until the late 80's when the rivers were drained for agriculture in front of the cave.

There is now a river bed in the lower galleries of Villars Cave that has been "fossilizing" for about 20 years; mudcracks appear at many places due to the desiccation of the sediments, water that infiltrates through fractures is slowly washing the gallery walls and small stalagmites (4-6 cm hight) are growing in some places; among them are our monitored stations \#1A and \#1B.

\section{Drip rates under stalactites : seasonal variations and air pressure constrained changes}

Home-made monitoring stations were first installed in January 1997 in the upper galleries (\#10A and \#10B) for convenience (electricity was easy to reach since located near the tourist path; Fig. 12a). These measured, every 10 minutes, the drip rate (infra red led counters), water volume, air pressure, conductivity and $\mathrm{pH}$ (the latter for only a few months). Dripping

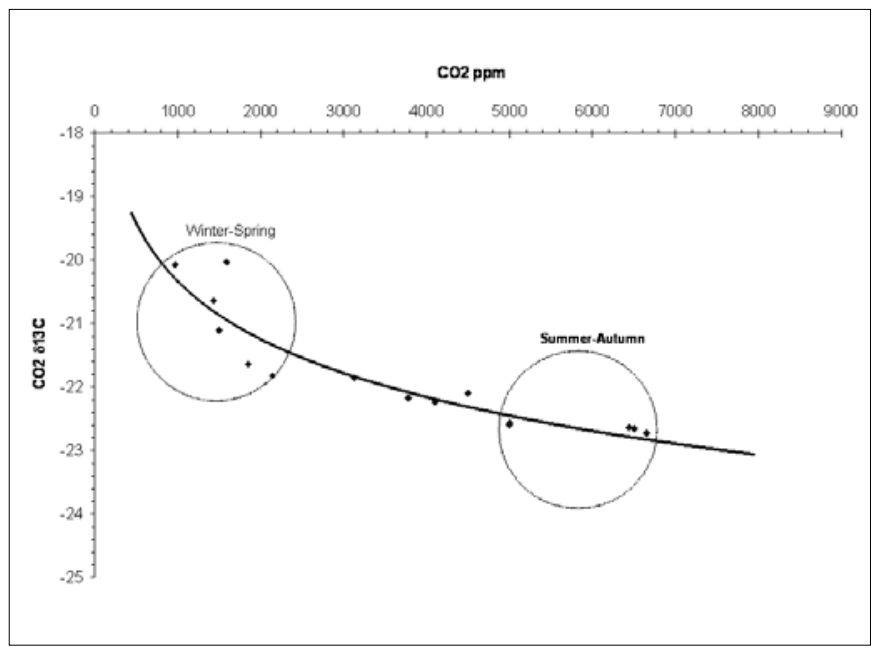

Fig. 11. Correlation between the $\mathrm{CO}_{2}$ concentration of the Villars Cave air and its isotopic composition (from Genty et al. unpublished). 


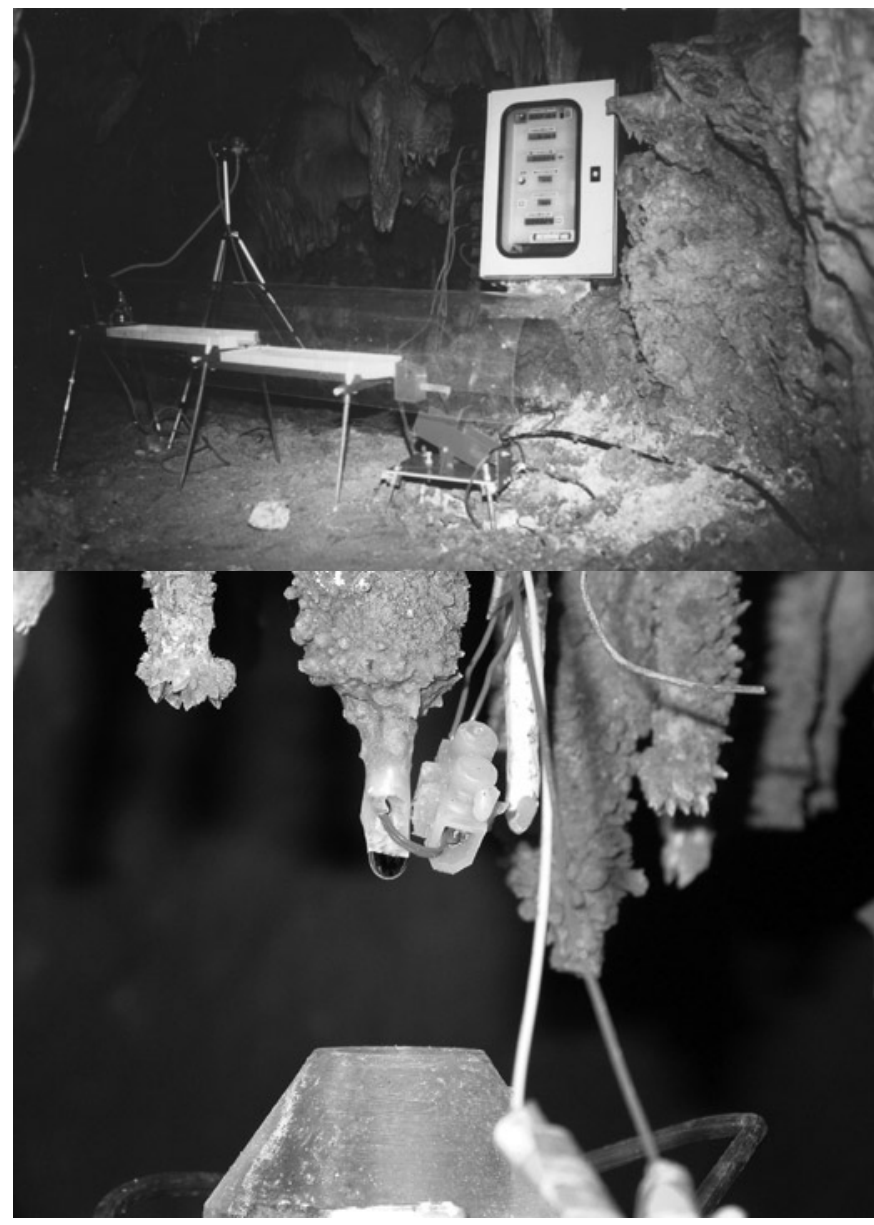

Fig. 12. (top) First automatic station set up in the Villars Cave (with the help of Guy Deflandre and Yves Quinif, Faculté Polytechnique de Mons, Belgium, who were among the first to install such a home made monitoring station in the Père-Noël cave, Belgium, in 1991); (bottom) Sensors connected to the second automatic station installed in September 2001: temperatures (air-water), drip rate and air pressure are recorded every minute with an autonomy of more than 8 months (M. Van Ruymbeck conception, Obervatoire Royal de Belgique).

stations from the lower galleries (\#1A, \#1B) were monitored manually at about one month intervals. Another automatic station replaced the first one in November 2001 with new sensors (water temperature, air temperature) and higher frequency measurements (every minute, $\mu$ das stations were installed by M. Van Ruymbeck, ORB, Bruxelles, Fig. 12b). For a few years now, independent drip rate counters STALAGMATE (Collister \& Mattey, 2008) have been put under stalactites in the lower galleries (\#1A, \#1B) and in the upper ones (\#10A, \#10B).

In all places studied, the drip rate displays a well marked seasonal variation. The drip rate in stations \#10A and \#10B starts to increase abruptly during November or December, it stays high until May or June, then, in summer, the drip rate is much lower until the end of autumn (Fig. 13). Comparison between drip rate measurements and the water excess calculation (with nearby meteorological station Nontron, $15 \mathrm{~km}$ far) shows that there is a time delay of between one to two months before the water enters the cave where the automatic station has been put (Fig. 13). It is interesting to note that, despite the fact that the two stalactites where the automatic drip counters have

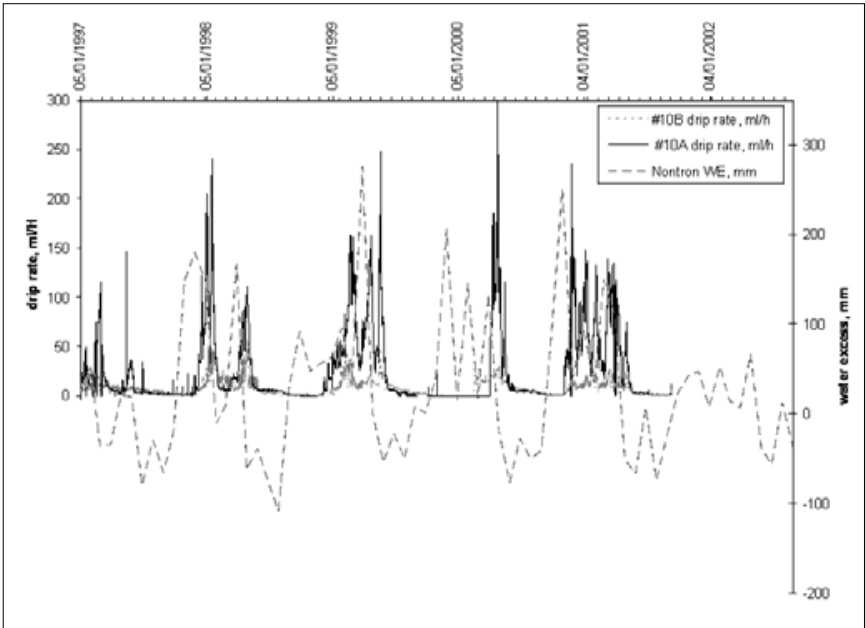

Fig. 13. Example of drip rate changes at stations \#10A and \#10B in the Villars Cave; comparison with the water excess (estimated with the Thornwaite formulae, see Genty et al. 1998 for details). Note the well marked seasonal drip rates on both stations and the time delay of a few weeks between the water excess and the drip rate.

been put are less than $4 \mathrm{~m}$ from each other and at the same depth/surface, they display different drip rate behaviours: one is more sensitive to the external water excess (\#10A) while the other (\#10B) shows lower drip rate amplitudes and is time-delayed compared to the first one (Table 1). This is likely the consequence of a different geomorphology in the fissure network that feeds the stalactite: the \#10B is possibly fed by smaller conduits with less direct connections with the surface. The annual quantity of water coming out from the \#10B station is, on average, between 1995 and 2007, 386.1 litres while it is about 1313.7 litres for the \#10A. In the lower galleries there is also such contrasted drip rates between the two nearby stations \#1A and \#1B (Table 1).

On a daily scale observation, the drip rate of \#10A is correlated with the cave air pressure (similar to the external air pressure) (Fig. 14) : when the air pressure increases, the drip rate slows down, like already observed in Père-Noël Cave, Belgium (Genty \& Deflandre, 1998). This was explained by a stress due to the air pressure on the rock formation which closes the small fissures near the stalactite and consequently decreases the drip rate. However, in Villars, this is not a rule and this correlation is not always observed during the entire year, moreover, it is not observed with the \#10B drip rate station. This suggests that the sensitivity of the fissure network to the air pressure changes is also different from one place to the other and might be linked with the depth of the monitoring station/surface and with the morphology of the fissure network.

There are also differences between the deeper galleries and the upper ones: the former display a higher minimum drip rate while the latter nearly stop during the dry season (Table 1). This clearly illustrates the reservoir volume differences between the upper and the lower galleries, but the yearly quantities of water coming out of the stalactites are comparable in both gallery levels. 


\begin{tabular}{|c|c|c|c|c|}
\hline Station & mean $\mathbf{m l} / \mathbf{m i n}$ & $\max \mathbf{m l} / \mathbf{m i n}$ & $\min \mathbf{m l} / \mathbf{m i n}$ & mean litres/year \\
\hline Villars, \#1A & 0.73 & 2.69 & 0.19 & 382.5 \\
\hline Villars, \#1B & 2.56 & 9.0 & 0.25 & 1347.9 \\
\hline Villars, \#10A & 2.69 & 12.9 & 0.015 & 1413.7 \\
\hline Villars, \#10B & 0.73 & 2.5 & 0.013 & 386.1 \\
\hline
\end{tabular}

Table 1. Drip rate characteristics of the four Villars Cave stations between July 1995 and September 2007. Note that stations of the lower galleries $(\# 1 \mathrm{~A}, \# 1 \mathrm{~B})$ display high minimum drip rates than in the upper galleries (\#10A, \#10B), note also the great variability of station \#10A. The drip rate calibration was made with an average drop volume of $0.15 \mathrm{ml}$.

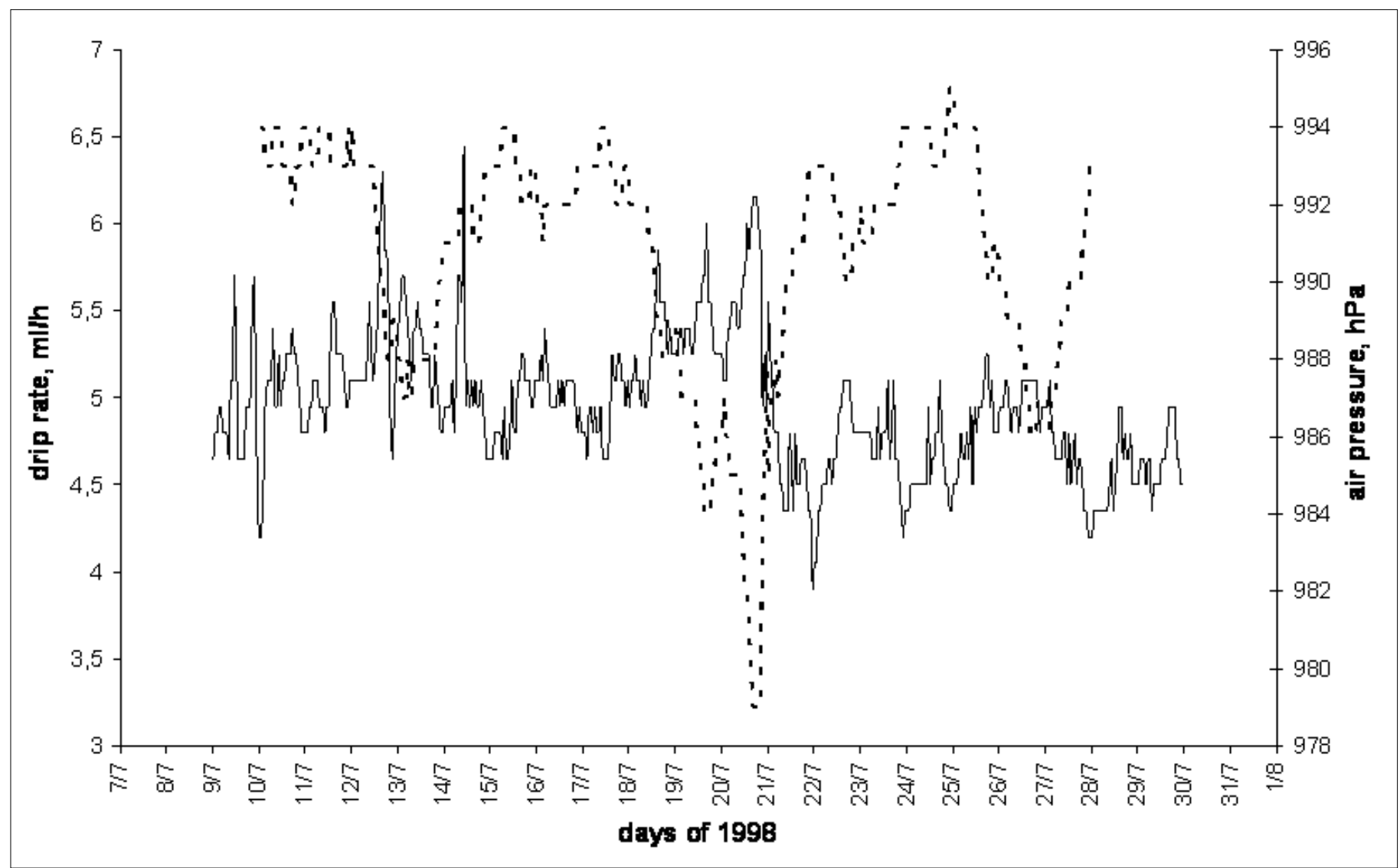

Fig. 14. Opposite correlation between the drip rate under stalactite \#10A (continuous line) and the cave air pressure during July 1998.

\section{TEMPERATURE CHANGES IN VILLARS CAVE}

Temperatures have been measured monthly since 1997 in the lower galleries (stations \# 1A and \#1B; 30 $\mathrm{m}$ deep and $200 \mathrm{~m}$ far from the entrance) and in the upper ones (stations \# 10A and \# 10B; 15 m deep and 30 $\mathrm{m}$ from the entrance). The lower galleries' temperature is about $1^{\circ} \mathrm{C}$ colder $\left(\sim 11.4^{\circ} \mathrm{C} \pm 0.1\right)$ than that of the upper galleries $\left(\sim 12.5^{\circ} \mathrm{C} \pm 0.3\right.$ on average $)$ and does not show seasonal variations. The seasonal variation is about $1^{\circ} \mathrm{C} \pm 0.3$ in the upper galleries (stations \#10A and \#10B): the temperature minimum (11.9 to $12.2{ }^{\circ} \mathrm{C}$ ) occurs in May and the maximum occurs in October $\left(12.8\right.$ to $\left.13.4^{\circ} \mathrm{C}\right)$ (Fig. 15). Compared with the outside seasonal variation, there is a time offset of about two months for the temperature maximum and 3-4 months for the temperature minimum (Fig. 15). Despite the relatively short number of annual cycles monitored, it appears that the seasonal amplitude increases: it was $0.8^{\circ} \mathrm{C}$ in 1997 and 1998 , it went up to $1.1^{\circ} \mathrm{C}$ in 2003 , possibly because of the exceptional warm summer temperatures of this year (see the temperature peak on Fig. 15), but continued to be higher during the last cycles: $1.4^{\circ} \mathrm{C}$ in 2005 and 1.1 ${ }^{\circ} \mathrm{C}$ in 2006.

An interesting feature is that since we have monitored Villars Cave temperature regularly (i.e. 10 years), we have observed a warming trend in both deep and shallow galleries of about $+0.4^{\circ} \mathrm{C} \pm 0.1 / 10$ years: the lower galleries' temperature is now $11.6^{\circ} \mathrm{C}$ while it was $11.1^{\circ} \mathrm{C}$ in 1997 , and the upper galleries display an average temperature of $12.7^{\circ} \mathrm{C}$ now while it was $12.3^{\circ} \mathrm{C}$ in 1997 (Fig. 16). There is a possible warming effect due to the tourist visits during the summer (July and August essentially, during which several hundreds of visitors go into the cave each day) that is difficult to quantify; however, the fact that the tourist path is only about $200 \mathrm{~m}$ long in comparison to a total gallery network of more than $10 \mathrm{~km}$ long likely makes this impact low at the seasonal scale. A more likely cause of this warming is the external warming that is observed in several meteorological stations around Villars Cave (Nontron and Limoges; 


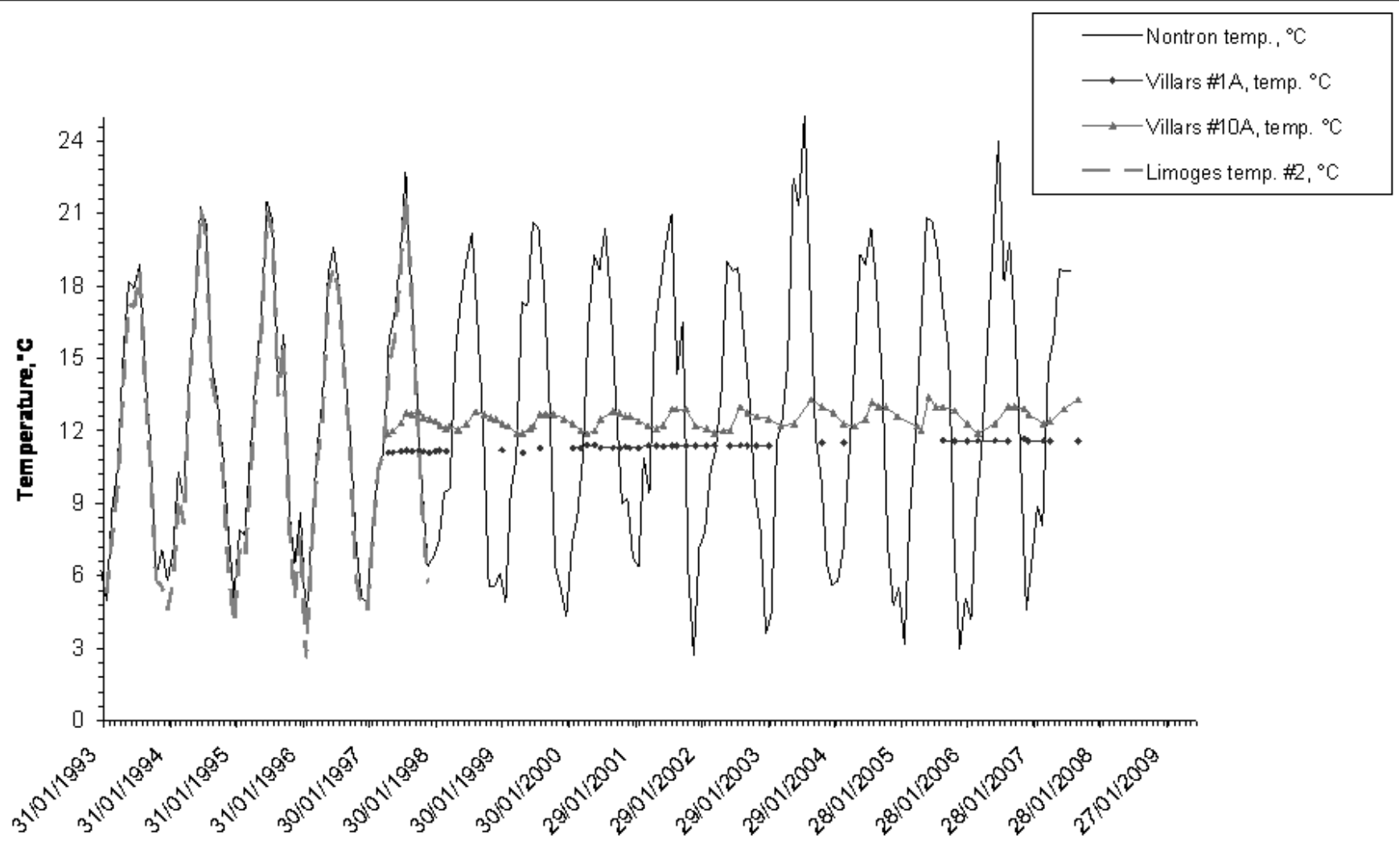

Fig. 15. Temperature changes in the Villars cave, comparison with the external temperature of the nearby Nontron and Limoges meteorological stations (O. Mestre, Météo France). Note the well marked seasonal variation in the upper galleries (\#10A) and the stable temperatures in the lower galleries $(\# 1 \mathrm{~A})$. Note also the warming trend of about $0.4^{\circ} \mathrm{C} / 10$ years in Villars galleries and a similar one in the external temperatures.

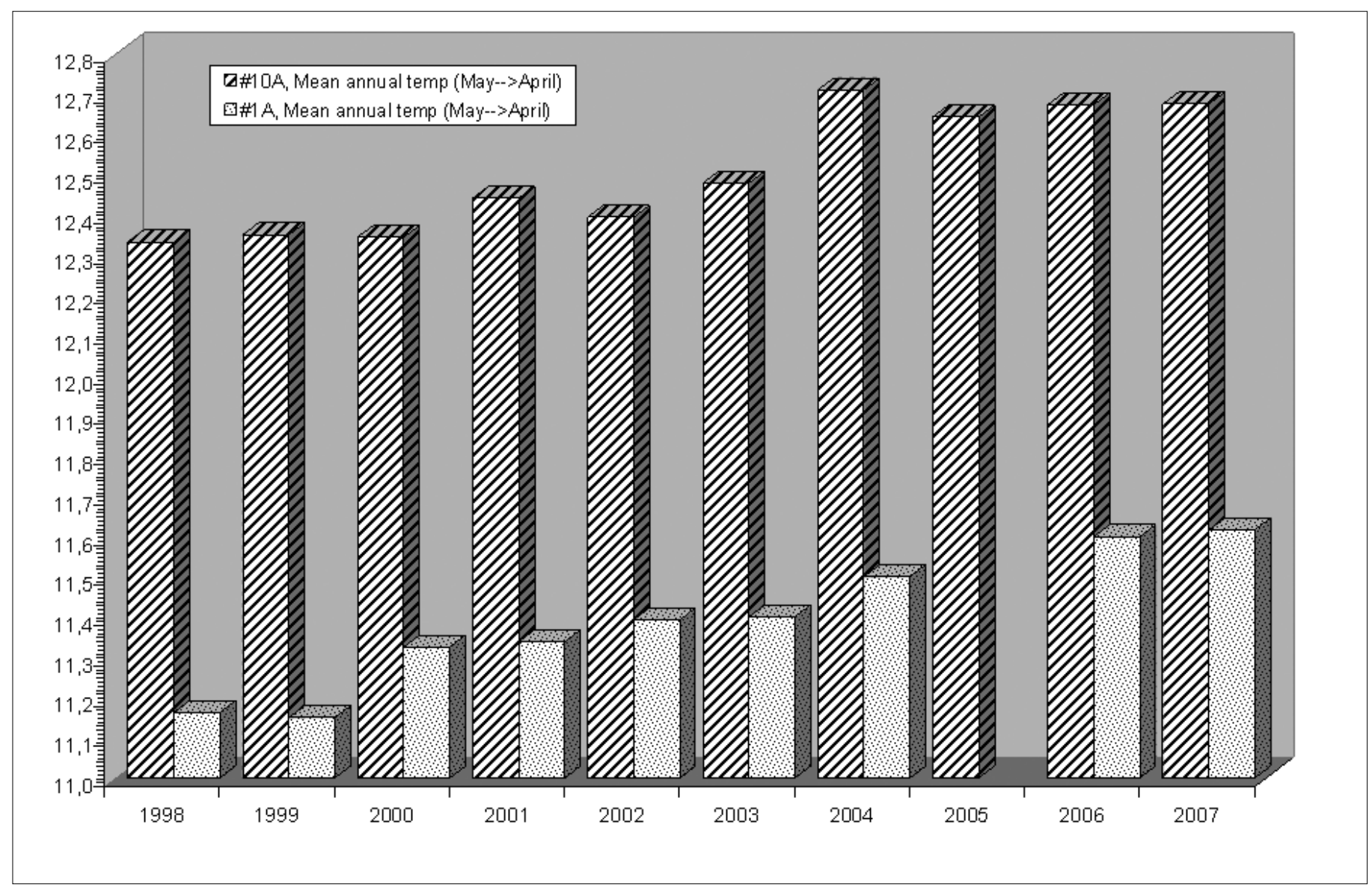

Fig. 16 - Average mean temperature in the Villars Cave showing a warming trend of about $+0.4^{\circ} \mathrm{C} / 10$ years. Average annual temperatures are from May to April, which coincide with minima (missing 2005 value is due to no data gathering in the lower galleries). 
both stations display similar temperature variations for cross cover periods): the warming trend in the outside atmosphere is $\sim 1.1^{\circ} \mathrm{C} / 10$ years between October 1967 and present day (over a 40-years period) which is greater than the one measured in Villars Cave (Fig. 17). The outside temperature warming trend was lower at the beginning of the record (i.e. in the seventies and eighties), and increased significantly between 1985 and 1997. Thus it may be possible that the thermal wave conduction through the limestone due to the warming takes several decades to reach the underground galleries of the Villars cave; this would explain both the different temperature between the lower and the upper galleries and the inter-annual warming trend.

\section{SEEPAGE WATER ISOTOPIC COMPOSITION AND ITS LINK WITH RAINFALL}

Four dripping stations have been monitored regularly for ten years in Villars Cave: two from the upper galleries (\#10A, \#10B) and two from the lower galleries (\#1A, \#1B; Fig. 2 and 6). Parallel to this, rainfall isotopic composition has been monitored in two places: one just above Villars Cave, the other one $50 \mathrm{~km}$ south at the same altitude (Le Mas). The local meteoric water line is very similar in both stations with a slope of 7.33 which is slightly lower than the WMWL (Fig. 18). Note that all the dripping water is gathered in a small set located slightly above the LWML (higher $\delta D)$, station \#10A showing the most scattered values. The reason for this is not clear, condensation might produce such phenomenon as observed in Caverne de l'Ours, Quebec, where temperature changes (> $5^{\circ} \mathrm{C}$ ) cause seasonal changes in the relative humidity and thus condensation with relatively higher $\delta D$ values (Lacelle et al., 2004). Despite the fact that the temperature is very stable in the lower galleries in Villars Cave and do not show seasonal variation and are very humid ( $\mathrm{RH}>95 \%)$, it may be possible that in the epikarst near the surface, the temperature in the fissures and conduits changes significantly (as observed in the upper galleries) and then produces condensation water that contributes to the seepage water. An exchange with the cave vapour in a very high humidity environment might also be possible, but this has to be demonstrated, for example by measuring the isotopic content of the vapour.

The isotopic composition of three dripping stations is very stable all year long and from one year to the next: $\delta^{18} \mathrm{O}=-6.39 \%$ o $(1 \sigma=0.06)$ for the station \#1A, $\delta^{18} \mathrm{O}=-6.41 \%$ o $(1 \sigma=0.06)$ for the station \# $1 \mathrm{~B}$ and $\delta^{18} 0$ $=-6.20 \%$ o $(1 \sigma=0.06)$ for station \#10B (Fig. 19). The station \#10A, which shows the highest sensitivity to the rainfall, displays the most variable isotopic composition: $\delta^{18} \mathrm{O}=-6.22 \%$ o $(1 \sigma=0.23)$. Note that both stations that are in the lower galleries (\#1A and $\# 1 B)$ have the lowest $\delta^{18} \mathrm{O}(-6.39$ and $-6.41 \%)$ while the upper galleries stations (\#10A and \#10B) have a significantly higher $\delta^{18} \mathrm{O}(-6.2$ and $-6.22 \%$ o). This is also true for the deuterium values, which explains the position of \#10A and \#10B above \#1A and \#1B in figure 18. Why the lower dripping stations have the lowest isotopic composition is not clear. It can be due to a contribution of older water from older

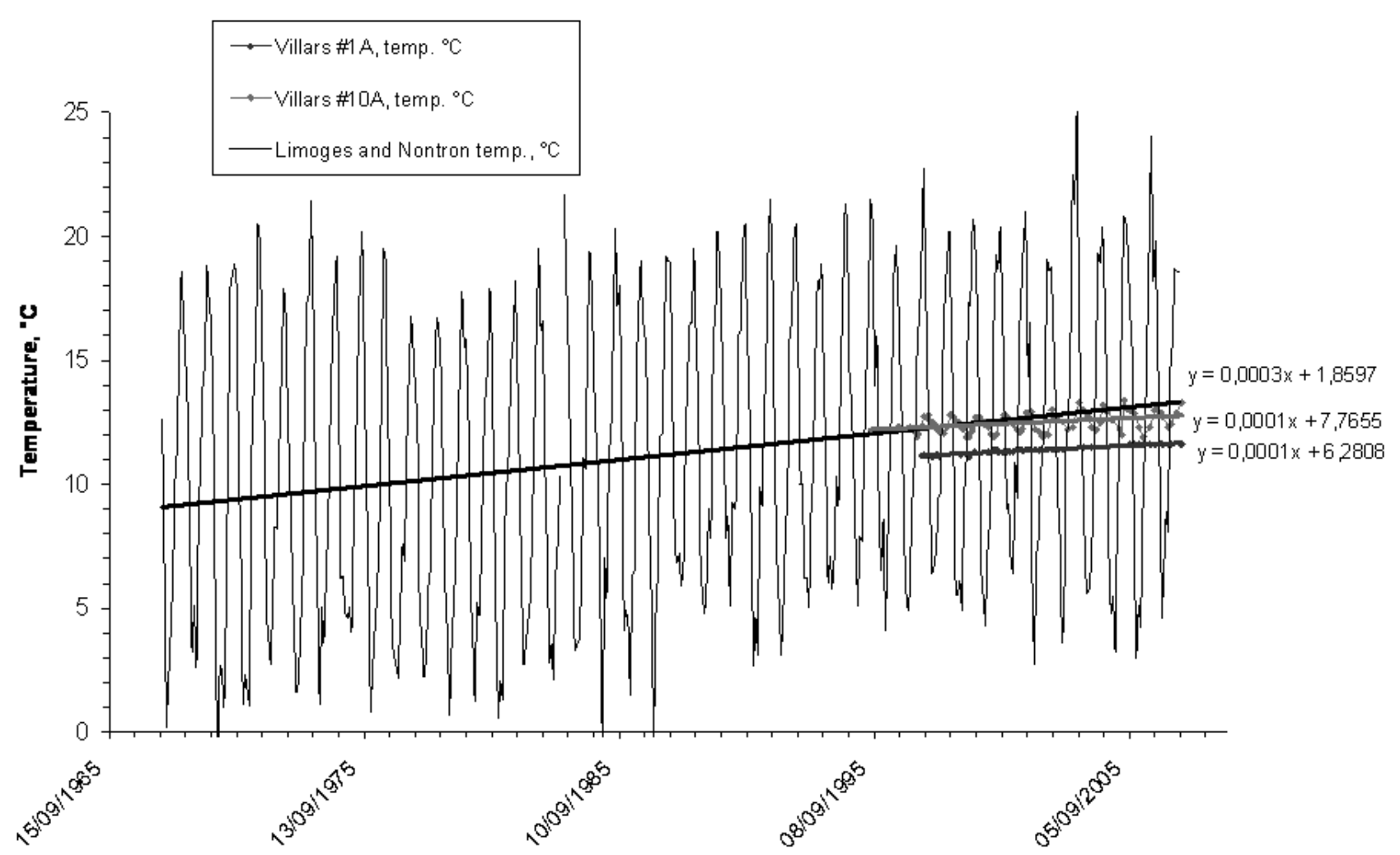

Fig. 17. Comparison of the warming trend in the Villars Cave with the one observed in the nearby meteorological stations (large temperature variations are from the outside meteorological station; small seasonal amplitude variations are from the Vil\#10A station of the upper galleries, and no seasonality is observed in the Vil\#1A station in the lower galleries). 


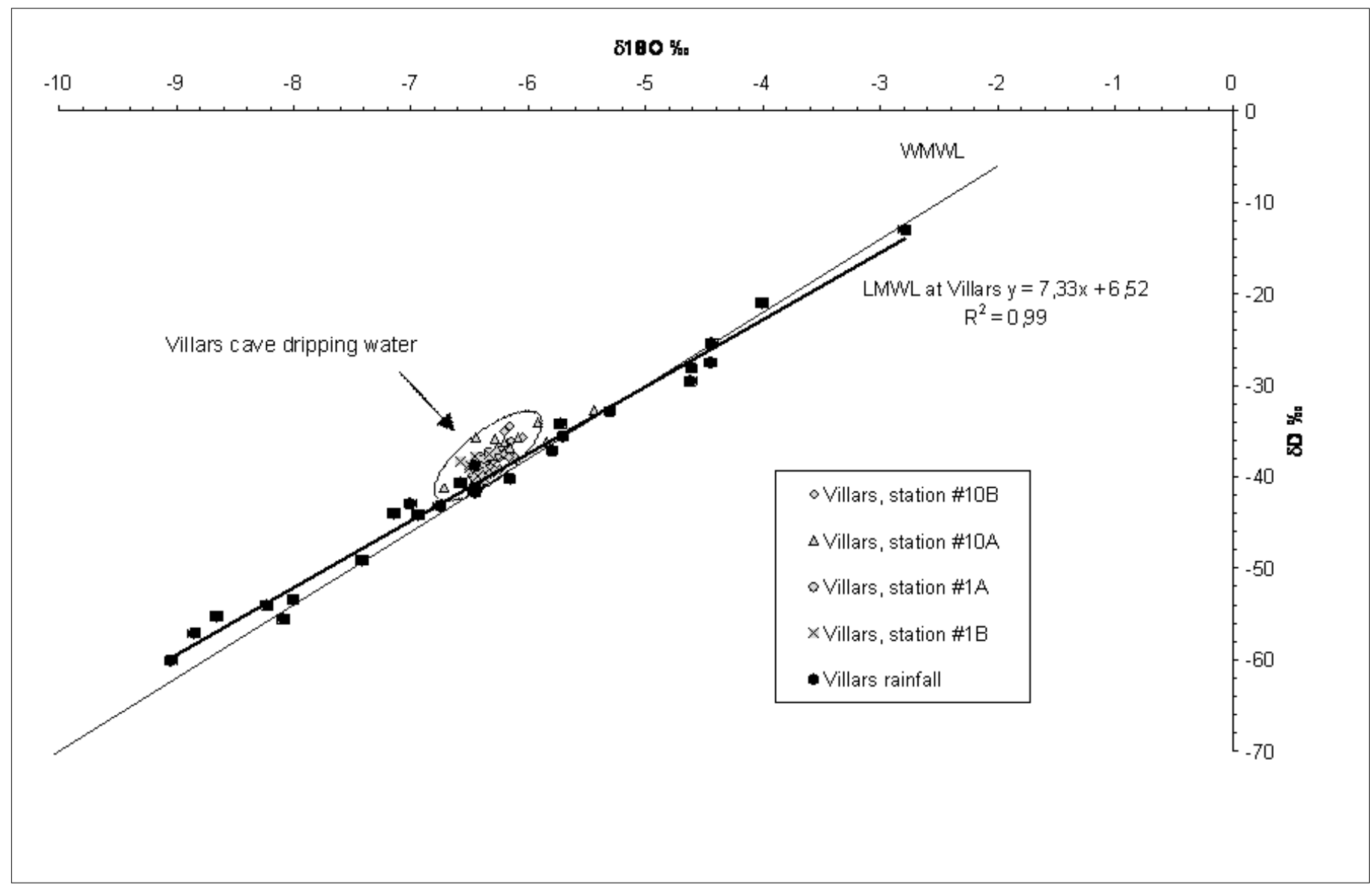

Fig. 18. Isotopic composition of the Villars cave dripping water and of the rainfall since 10 years. Note that all the dripping water is gathered in a small set slightly above the LWML. Analytical errors are shown by the black error bars: $0.05 \% 0$ for the $\delta^{18} \mathrm{O}$ and $0.5 \% 0$ for the $\delta \mathrm{D}$.

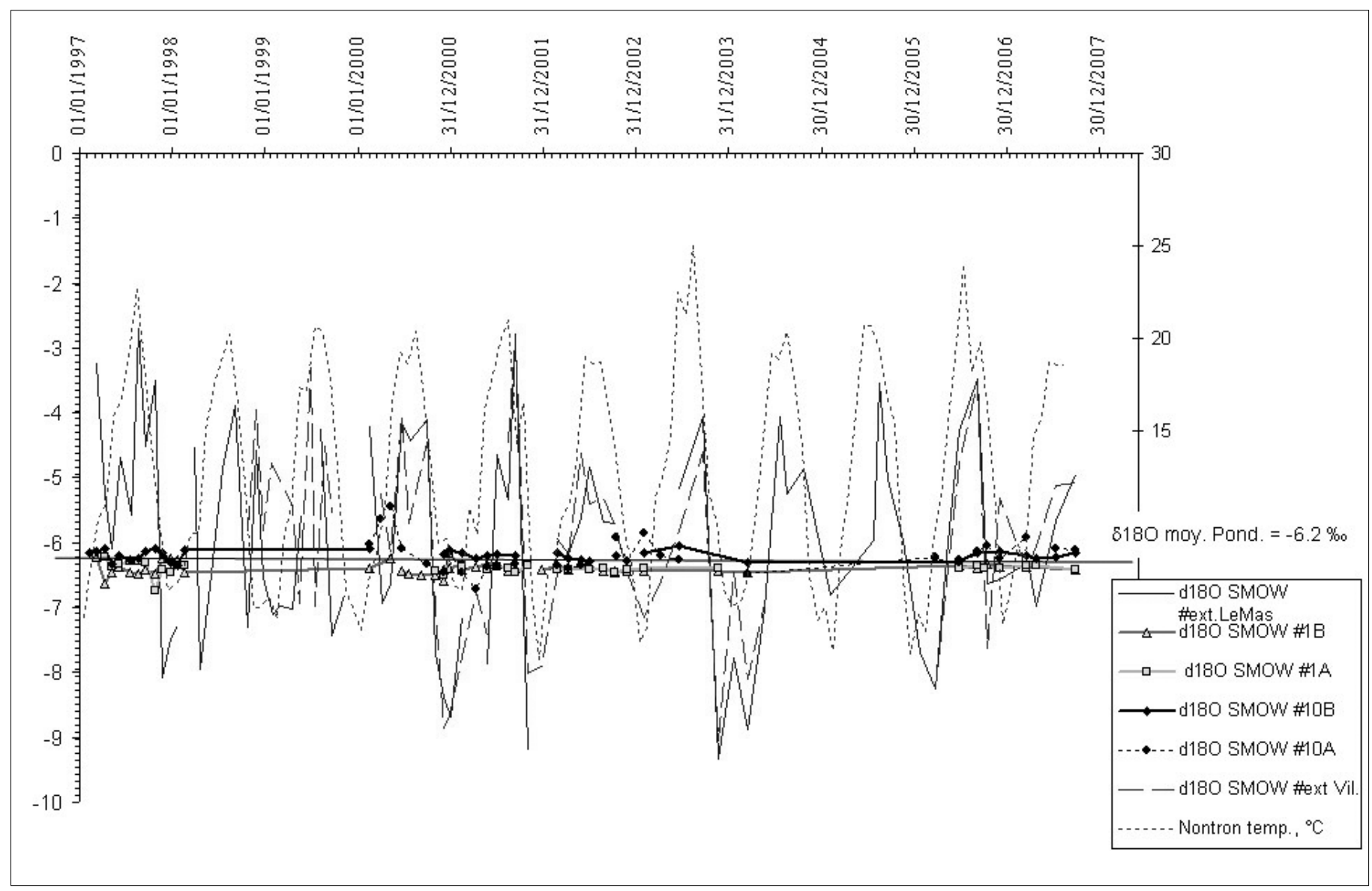

Fig. 19. Time series of the isotopic composition of the Villars Cave dripping water. Comparison with the rainfall isotopic composition of the in situ meteorological station (\#ext Vil.) and with the Le Mas Station (about $50 \mathrm{~km}$ south far). 
rainfalls whose $\delta^{18} \mathrm{O}$ was lower. This is coherent with the meteorological data that have shown that the averaged outside temperature was much lower in the former decades at Nontron and at Limoges (Fig. 17) which likely yield a lower precipitation $\delta^{18} \mathrm{O}$ above Villars Cave. Simulated rainfall $\delta^{18} \mathrm{O}$ near Villars using the REMO program (Sturm et al., 2005; Pierre Alain Danis and Georg Hoffmann communications) seems to confirm this hypothesis: reconstructed rainfall $\delta^{18} \mathrm{O}$ from 1960 to 2001 yield an average increasing trend of $+0.146 \%$ o 10 years, then, in order to explain the $+0.2 \%$ difference between the lower and the upper galleries, a theoretical age difference in the rainfall feeding the seepage water is 13.6 years. Tritium measurements on dripping water will eventually confirm this hypothesis.

The average weighted isotopic composition of the rainfall all year long is $-6.2 \%$, which is similar to the mean values of stations \#10A and \#10B. This observation confirms the hypothesis that the deeper dripping stations are "contaminated" by older waters, otherwise their lower isotopic composition is difficult to explain.

\section{DRIPPING WATER CHEMISTRY}

The chemistry (main cations, anions and a few trace elements) of the seepage water was monitored every two months between November 2000 and June 2002 at the four stations \#1A, \#1B, \#10A and \#10B (Table 2). At the same time, the rainfall was analysed at a station just above the cave and at the Le Mas station, $50 \mathrm{~km}$ south. We present here a few results of this monitoring that display marked differences between deep and shallow dripping stations (Fig. 20).
The $\mathrm{Ca}^{2+}$ concentrations of the Villars Cave dripping stations are relatively high compared to other cave waters but in the same range of South-France cave dripping waters (Dreybrodt, 1988; Fairchild et al., 2006; Ford \& Williams, 1992; Genty et al., 2001b; Huang et al., 2001). The most striking feature of these analyses is that, first, two close stations show similar concentrations, and second, the lower gallery stations have much higher element concentrations than the upper galleries (Fig. 20). For example, the $\mathrm{Ca}^{2+}$ average concentration is $130 \mathrm{ppm}$ in the lower stations, while it is $80 \mathrm{ppm}$ in the upper galleries; similarly, the $\mathrm{Sr}^{2+}, \mathrm{Mg}^{2+}$ and $\mathrm{Ba}^{2+}$ are twice as concentrated in the lower stations than in the upper ones (Table 2). The uranium concentrations are about three times higher in the \#1A and \#1B stations than in the \#10A and \#10B ones. The vegetation is the same above all these dripping stations and the geology is the same (oolithic limestone of the Bajocian). Despite invisible heterogeneity in the limestone formation, the only difference between upper and lower dripping stations is the depth, and thus the length of the micro fissure network where water/rock exchanges occur. The depth (height of limestone between the external surface and the gallery roof) difference between lower and upper stations is estimated to be between 10 and 20 metres, which is not so great compared with other caves where galleries may be separated by several decametres. We see here the great impact of this small depth difference in the dripping water chemistry, which is likely the consequence of the difference in the residence time in the fissure network. There is no direct link between the chemistry (Table 2) and the mean drip rates or the drip rate variability (Table 3),
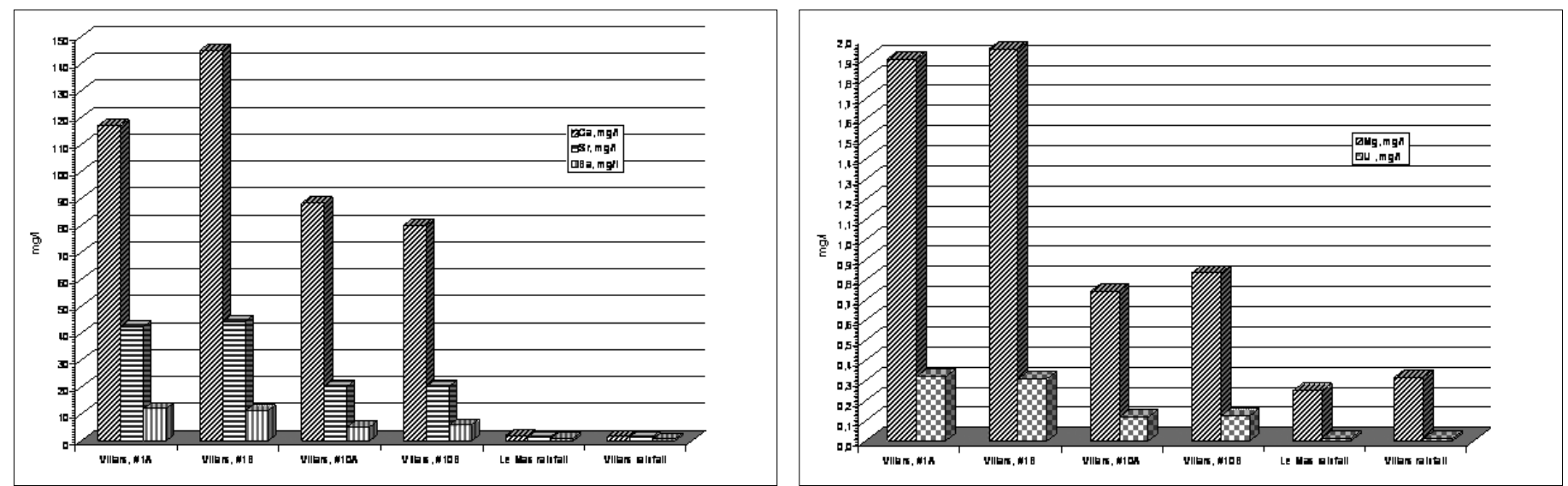

Fig. 20. Geochemical concentrations of the Villars Cave dripping stations and in the rainfall (averaged monthly values of 2000-2001 AD.

\begin{tabular}{|c|c|c|c|c|c|}
\hline Station & Ca, $\mathbf{m g} / \mathbf{l}$ & $\mathbf{M g}, \mathbf{m g} / \mathbf{l}$ & $\mathbf{S r}, \mathbf{m g} / \mathbf{l}$ & Ba, $\mathbf{m g} / \mathbf{l}$ & $\mathbf{U}, \mathbf{m g} / \mathbf{l}$ \\
\hline Villars, \#1A & 117.0 & 1.9 & 42.4 & 11.9 & 0.32 \\
\hline Villars, \#1B & 145.0 & 1.9 & 44.3 & 11.2 & 0.31 \\
\hline Villars, \#10A & 88.3 & 0.7 & 20.2 & 5.1 & 0.12 \\
\hline Villars, \#10B & 79.9 & 0.8 & 20.1 & 5.8 & 0.12 \\
\hline Le Mans rinfall & 2.0 & 0.2 & 1.5 & 0.9 & 0.01 \\
\hline Villars rainfall & 1.6 & 0.3 & 1.5 & 0.7 & 0.01 \\
\hline
\end{tabular}

Table 2. Average composition of the dripping water of the Villars Cave between November 2000 and June 2002 at different places, comparison with the rainfall composition. Errors are $\pm 0.5 \mathrm{mg} / \mathrm{l}$ for $\mathrm{Ca}, \mathrm{Mg}, \mathrm{Sr}$, Ba and \pm 0.05 for $\mathrm{U}$. 


\begin{tabular}{|c|c|c|c|c|c|c|c|}
\hline Station & $\begin{array}{c}\text { Measured } \\
\text { cave air T, }{ }^{\circ} \mathrm{C}\end{array}$ & $1 \sigma$ & $\begin{array}{c}\text { Water } \delta^{18} \mathbf{O} \\
\text { SMOW } \pm 0.08\end{array}$ & $\begin{array}{l}\text { Calcite } \delta^{18} O \\
\text { PDB } \pm 0.05\end{array}$ & $\begin{array}{c}\text { Kim and O'Neil } \\
\text { T, }{ }^{\circ} \mathrm{C}\end{array}$ & O'Neil T, ${ }^{\circ} \mathrm{C}$ & Craig $\mathrm{T},{ }^{\circ} \mathrm{C}$ \\
\hline Vil\#1A & 11.26 & 0.16 & -6.4 & -4.87 & 6.98 & 8.16 & 10.78 \\
\hline Vil\#1B & 11.26 & 0.16 & -6.42 & -4.68 & 6.07 & 7.30 & 9.99 \\
\hline Vil\#1B-stalagmate & 11.6 & 0.1 & -6.36 & -4.67 & 6.29 & 7.50 & 10.17 \\
\hline VILgal1B-0 & 11.47 & 0.12 & -6.42 & -4.74 & 6.34 & 7.55 & 10.22 \\
\hline VILgal1B-7 & 11.47 & 0.12 & -6.42 & -5.10 & 7.88 & 9.02 & 11.57 \\
\hline VILgal1B-14 & 11.47 & 0.12 & -6.42 & -4.92 & 7.13 & 8.31 & 10.91 \\
\hline VILgal1B-20 & 11.47 & 0.12 & -6.42 & -4.95 & 7.22 & 8.39 & 10.99 \\
\hline VILgal1B-24 & 11.47 & 0.12 & -6.42 & -5.06 & 7.71 & 8.86 & 11.42 \\
\hline VILgal1B-30 & 11.47 & 0.12 & -6.42 & -4.99 & 7.40 & 8.56 & 11.14 \\
\hline VILgal1B-38 & 11.47 & 0.12 & -6.42 & -5.02 & 7.56 & 8.71 & 11.29 \\
\hline VILgal1B-43.5 & 11.47 & 0.12 & -6.42 & -4.85 & 6.80 & 8.00 & 10.62 \\
\hline Vil\#8 & 11.38 & 0.19 & -6.26 & -4.65 & 5.99 & 7.81 & 10.47 \\
\hline Vilplq8 & 11.38 & 0.19 & -6.26 & -5.08 & 6.63 & 9.60 & 12.13 \\
\hline Vil\#10A & 12.43 & 0.35 & -6.23 & -4.47 & 8.51 & 7.19 & 9.91 \\
\hline
\end{tabular}

Table 3 - Isotopic composition of the modern deposits from the Villars Cave. Comparison between measured temperature and calculated temperatures using Kim and O'Neil 1997, O'Neil et al. 1969 and Craig 1965 equilibrium equations.

and, at least for the cations elements of table 2, the controlling factor appears to be the depth/surface of the gallery.

\section{MODERN CALCITE DEPOSITS}

The study of modern calcite allows us, firstly to know the present day isotopic equilibrium conditions of the calcite precipitation; secondly, when we have annual layers, it is a way to estimate the dead carbon proportion (dcp; the carbon proportion that comes from the limestone dissolution) and thus to better understand the carbon transfer from the surface to the speleothem.

\section{Present day isotopic equilibrium}

The isotopic equilibrium can be checked by using equilibrium fractionation formula where all variables are measured: temperature, dripping water $\delta^{18} \mathrm{O}$ and calcite $\delta^{18} \mathrm{O}$. Considering the O'Neil equilibrium formula (O'Neil et al., 1969) or the more recent one from Kim and O'Neil (Kim \& O'Neil, 1997), all the modern deposits studied in Villars Cave appear to be out of equilibrium: the calculated temperature is between $3^{\circ} \mathrm{C}$ to $4^{\circ} \mathrm{C}$ lower than the one measured (Table 3; Fig. 21). But, if we consider the Craig formula (Craig, 1965), the difference between measured and calculated temperature of 0.6 ${ }^{\circ} \mathrm{C}$ testifies to conditions much closer to the equilibrium especially if we take into account the errors on isotopic $( \pm 0.05 \%$ o $)$ and on temperature $\left( \pm 0.1^{\circ} \mathrm{C}\right)$ measurements (Fig. 21). Consequently, since the different equilibrium formulas do not show consistent results, the question of isotopic equilibrium on modern calcite deposit is not resolved. The fact that, when using the most recent paleotemperature formula from Kim and O'Neil (1997), the measured $\delta^{18} \mathrm{Oc}$ is much higher than the theoretical one is a sign of fractionation kinetics. In this way, these results confirm the early observations of Fantidis and Ehhalt, Fornaca-Rinaldi et al. and the more recent work of Mickler et al. that it is likely that many speleothems do not precipitate under isotopic equilibrium (Fantidis
\& Ehhalt, 1970; Fornaca-Rinaldi et al., 1968; Mickler et al., 2006), but more researches are needed to better constrain this question.

\section{Growth rates}

Modern calcite has been analysed in Villars Cave from deposits that developed on artificial tiles and pebbles placed under stalactites, and on the tip of small active stalagmites. Deposits on artificial supports allowed us to demonstrate that the regular visible laminae are annual (one alternation of white porous/dark compact calcite each year). It is striking to observe that modern (i.e. last 10 years) growth rates measured on well visible annual laminae in Villars are extremely high (Fig. 22): $1.75 \mathrm{~mm} / \mathrm{yr}$ from a deposit that grew on a flat tile between 1996 and 2000 (Fig. 22a) and $1.15 \mathrm{~mm} / \mathrm{yr}$ from a deposit that grew on a concave shaped quartz pebble between 2000 and 2007 (Fig. 22b). These high growth rates are explained by the high $\mathrm{Ca}^{2+}$ concentrations of the dripping water $(\sim 150 \mathrm{ppm})$ and by relatively fast drip rates at these stations (6 to $27 \mathrm{sec} /$ drip). But, such fast growth rates have also been found in ancient stalagmites, like at the base of Vilstm 1 where the annual laminae are up to $1.0 \mathrm{~mm}$ thick $\sim 3 \mathrm{ka}$ ago, suggesting that environmental conditions were close to the present day ones (Fig. 22c). Note that the shape of the support might have influenced the GR : the flat tile GR is higher likely because the water film is thicker than on the concave shaped pebble (see Dreybrodt model) (Dreybrodt, 1988). Thanks to the presence of annual laminae on several active stalagmites, we were able to construct solid chronologies which are used to study isotopic changes during the last decades, and especially ${ }^{14} \mathrm{C}$ variation that brings information about speleothem carbon sources and the dynamics of its transfer from the atmosphere to the precipitated calcite. 

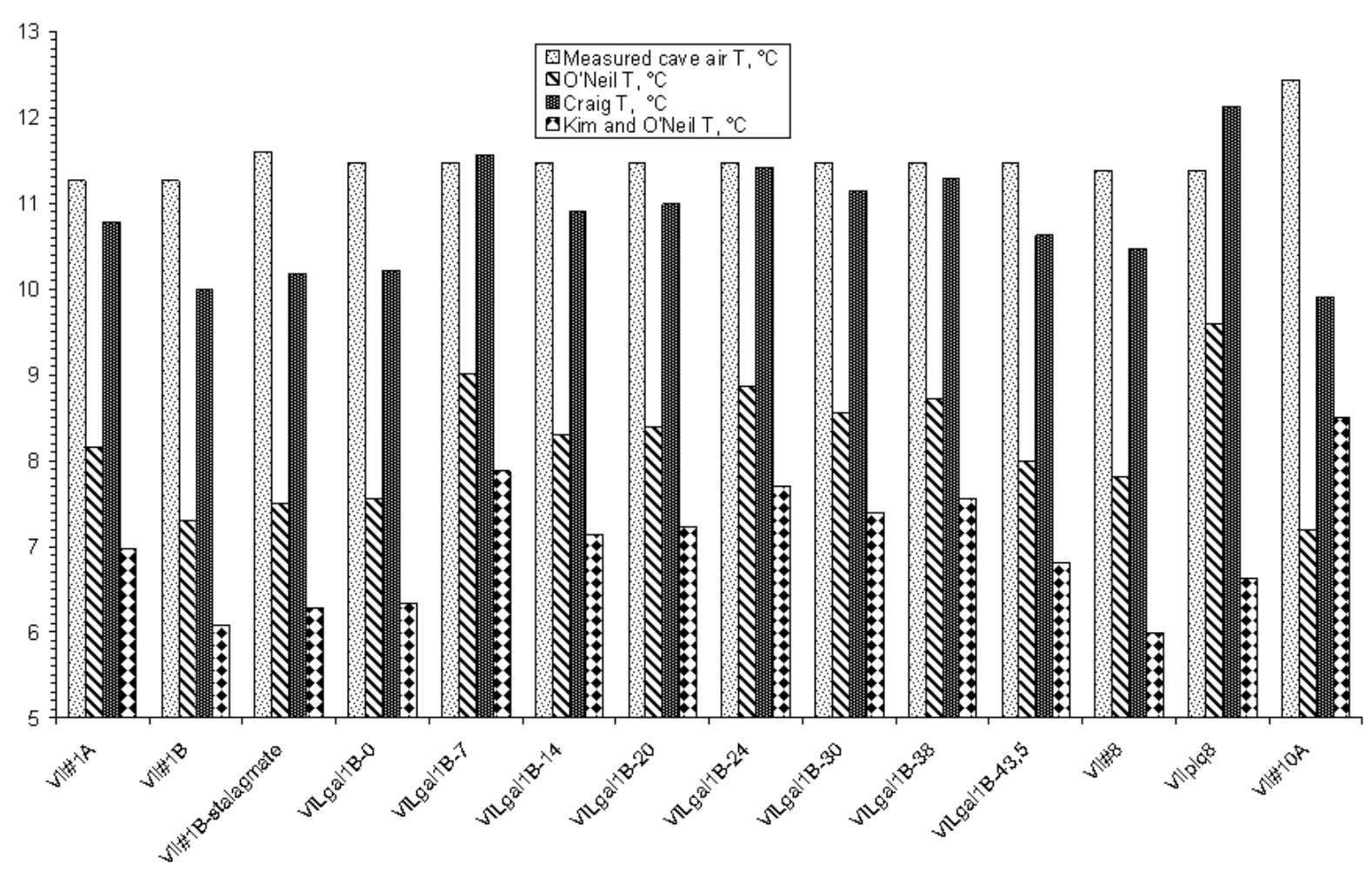

Fig. 21. Comparison between measured temperature and calculated temperature assuming an isotopic equilibrium between water and calcite. Note that the Craig temperature fits much better with the measured one than the other ones. We used the following temperature equations:

Craig $1965: \mathrm{T}\left({ }^{\circ} \mathrm{C}\right)=16.9-4.2^{*}\left(\delta^{18} \mathrm{Oc} \_\mathrm{PDB}-\delta^{18} \mathrm{Ow} \_\mathrm{SMOW}\right)+0.13\left(\delta^{18} \mathrm{Oc} \_\mathrm{PDB}-\delta^{18} \mathrm{Ow} \mathrm{SMOW}\right) 2$

O'Neil 1969 (from Friedman \& O'Neil, 1977) $\left.: \mathrm{T}\left({ }^{\circ} \mathrm{C}\right)=\sqrt{ }\left(2780000 / /\left(\left(\delta^{18} \mathrm{Oc} \_S M O W-\delta^{18} \mathrm{OW} \_S M O W\right)+2.89\right)\right)-273.15\right)$

Kim and O'Neil 1997 (from Leng \& Marshall, 2004): T $\left({ }^{\circ} \mathrm{C}\right)=13.8-4.58^{\star}\left(\delta^{18} \mathrm{Oc} \_P D B-\delta^{18} \mathrm{Ow} \_S M O W\right)+0.08\left(\delta^{18} \mathrm{Oc} \_\mathrm{PDB}-\delta^{18} \mathrm{Ow} \_S M O W\right) 2$

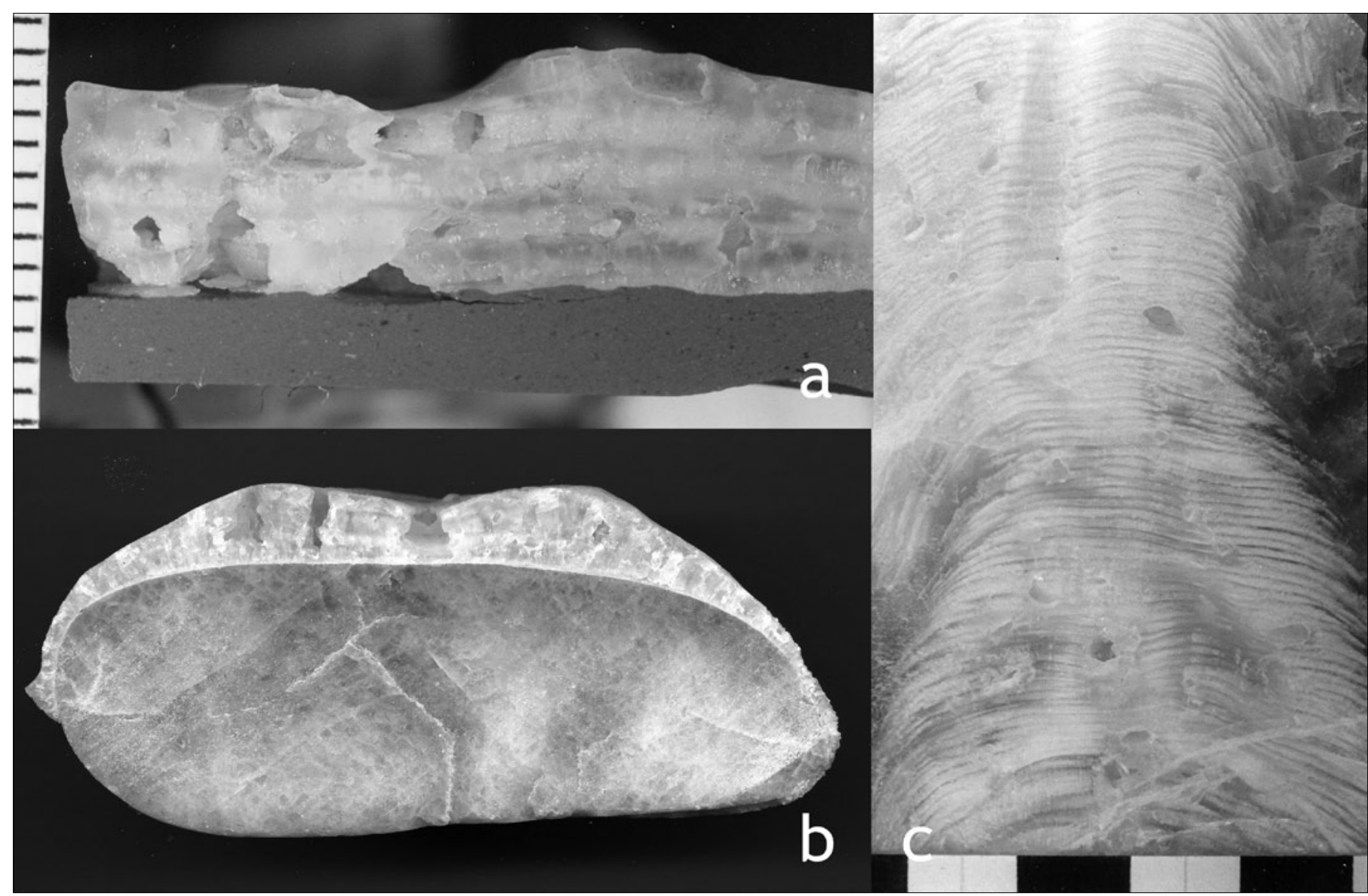

Fig. 22. Example of modern deposits from the Villars Cave: a) calcite that grew on a tile between the 22/8/1996 and the 26/9/2000, station \#8, $\mathrm{GR}=1.75 \mathrm{~mm} / \mathrm{yr}$; b) calcite that grew on a quartz pebble between the 27/09/2000 and the 19/11/2007, station \#1B, GR = $1.15 \mathrm{~mm} / \mathrm{yr}$. Comparison with a 3 ka old deposit where GR is comparable $(1.0 \mathrm{~mm} / \mathrm{yr})$. 


\section{Speleothem modern carbon sources}

The carbon of the calcite deposit has two main sources: the soil $\mathrm{CO}_{2}$ and the limestone $\mathrm{CaCO}_{3}$. Because the limestone dissolution occurs mainly in an open system (coincidence of $\mathrm{CO}_{2}$, water and limestone), and because the dissolution is controlled by several factors such as the fracture density network and the hydrology, the proportion of these two sources is variable (Drake, 1983; Ford \& Williams, 1992). Thanks to the detection of the nuclear bomb-test peak of the sixties in modern stalagmites we were able to quantify the proportion of the carbon that comes from the limestone dissolution and that is ${ }^{14} \mathrm{C}$ free, which is called the dead carbon proportion (dcp). Its average value, for European samples, is close to $15 \% \pm 5$, demonstrating that most of the carbon of speleothems comes from the soil $\mathrm{CO}_{2}$ (Genty et al., 2001a; Genty \& Massault, 1997; Genty \& Massault, 1999). In Villars Cave, the dcp was calculated at the top of the Vil-stm 1 stalagmite showing that $9.5 \% \pm 1.5$ of the carbon is from the limestone dissolution (Fig. 23). We used this dcp to estimate the ${ }^{14} \mathrm{C}$ age of the Vil-stm 1 stalagmite (after dcp correction and calibration) which are in good agreement with the U-Th ages (Genty et al., 1999). If a constant dcp may be applied on a recent sample like here ( 3 kyr old), it can not be applied on samples that cross cover large climatic changes such a deglaciation because changes in the vegetation activity and in the hydrology have a great impact on the dcp (Genty \& Baker, 2008).

\section{Carbon 13 trend in modern stalagmites}

The fact that most of the carbon of the $\mathrm{CaCO}_{3}$ molecules comes from the soil makes speleothems very sensitive to any vegetation and soil changes. We already mentioned that the vegetation in the Dordogne area developed greatly during the 20th century due to urban migration and the abandoning of agriculture,

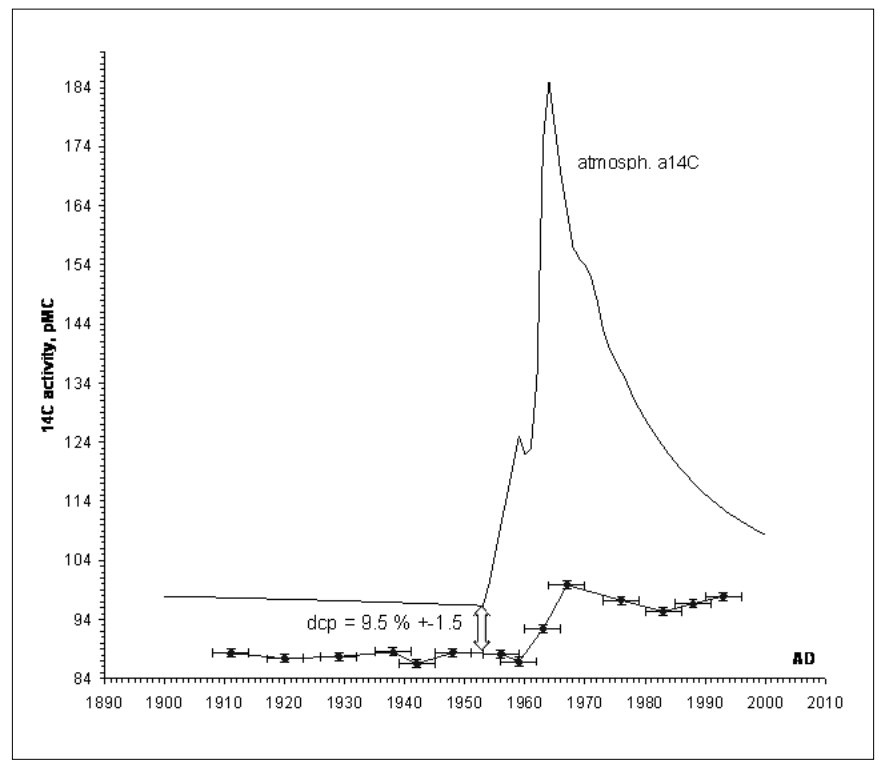

Fig. 23. Dead carbon proportion (dcp) measurement from a ${ }^{14} \mathrm{C}$ bomb signal recorded in the tip of vil-stm1 stalagmite, comparison with atmospheric ${ }^{14} \mathrm{C}$ activity. The dcp is the difference between the atmospheric ${ }^{14} \mathrm{C}$ activity at $\sim 1950$, before the nuclear bomb test increase, and the measured ${ }^{14} \mathrm{C}$ activity in the stalagmite $\mathrm{CaCO}_{3}$. with consequences on the soil $\mathrm{P}_{\mathrm{CO} 2}$ and thus on the calcite $\delta^{13} \mathrm{C}$ (Genty, 2003). Two modern stalagmites from Villars Cave, annually laminated, have been studied to see the $\delta^{13} \mathrm{C}$ variation. The first one, vilstm 1 , which grew under a grass field, displays a stable $\delta^{13} \mathrm{C}$ between $\sim 1910$ and $\sim 1990$ (Fig. 24). The second one, vil-\#1A, that grew under a forest, displays a well pronounced $\delta^{13} \mathrm{C}$ decreasing trend during its growth (between $\sim 1950$ and 1990 ). We suggest that, in the first case, the soil $\mathrm{P}_{\mathrm{CO} 2}$ is lower and was constant during the past century because the grass field did not change significantly. On the opposite, aerial photos (between 1950 and 2000) show that the forest above vil-\#1A location increased, trees expanded and aged, leading to a higher production of biogenic $\mathrm{CO}_{2}$ in the soil and the epikarst and then lowering $\delta^{13} \mathrm{C}$ in the dissolved inorganic carbon. This is a modern demonstration of the sensitivity of the speleothem to vegetation changes: changes in the activity intensity (and not vegetation type as all the plants here are of C3 type). The $2 \%$ higher value found in the vilstm $1 \delta^{13} \mathrm{C}$ profile is possibly a consequence of a lower soil $\mathrm{P}_{\mathrm{CO} 2}$ under the grass field compared with the one found under a forest. A $\delta^{13} \mathrm{C}$ decreasing trend was observed in modern stalagmites from Brown's Folly Mine (Wiltshire, England) and interpreted in the same way (Baldini et al., 2005).

\section{VILLARS CAVE PALAEOCLIMATIC RECORDS AND CONCLUDING REMARKS}

Monitoring hydrology, isotopes and chemistry, studying modern calcite deposits contributed to a better understanding of the Villars Cave isotopic speleothem records. If the link between meteorological data and calcite $\delta^{18} \mathrm{O}$ needs further research over a longer period (especially to see any correlation between interannual rainfall or temperature variations and seepage water $\delta^{18} \mathrm{O}$ ), the calcite $\delta^{13} \mathrm{C}$ is much better understood especially thanks to the analysis of the ${ }^{14} \mathrm{C}$ activity and $\delta^{13} \mathrm{C}$ in modern deposits. But other factors that might have influenced the $\delta^{13} \mathrm{C}$ composition in the past have to be more thoroughly studied, like the prior calcite precipitation or the drip rate changes (Baker et al., 1997; Fairchild et al., 2000). The specificity of the Villars

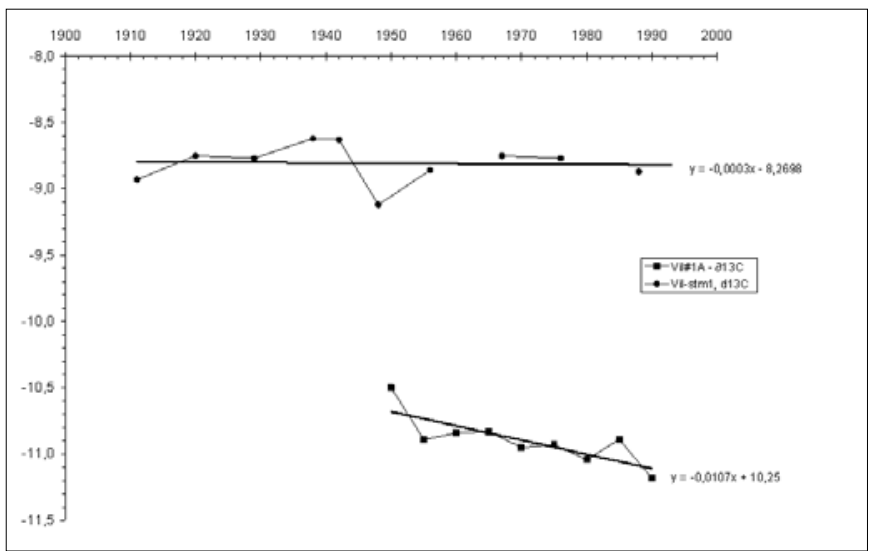

Fig. 24. $\delta^{13} \mathrm{C}$ changes in modern stalagmites from the Villars Cave. Note that Vil-\#1A that grew under a forest that developped since the last 50 years displays a decreasing $\delta^{13} \mathrm{C}$ trend while the Vil-stm1 that grew under a grass field does not show any trend. 
site, compared to most of the other locations that have produced speleothem palaeoclimatic records, is that the calcite $\delta^{13} \mathrm{C}$ responds well to past climatic changes while it is more uncertain for the $\delta^{18} \mathrm{Oc}$ (Genty et al., 2006; Genty et al., 2003).

This is likely due to several factors among which:

1) the proximity of the Atlantic Ocean that leads to a lower continental effect of the rainfall $\delta^{18} \mathrm{O}$ and thus to a lower sensivity to atmospheric circulation changes (Rozanski et al., 1993);
2) to the oceanic temperate climate which is humid enough to allow forest development most of the time and prevent $\mathrm{C} 4$ type plants that would have complicated the $\delta^{13} \mathrm{C}$ interpretation.

In this way, past climatic changes have been recognized in several stalagmites from Villars Cave during the last 90 ka (Fig. 25): the Last Deglaciation with the YoungerDryas and the Bølling-Allerød (Genty et al., 2006), the Dansgaard-Oeschger events of the MIS 4 and 3 (Genty et al., 2003).

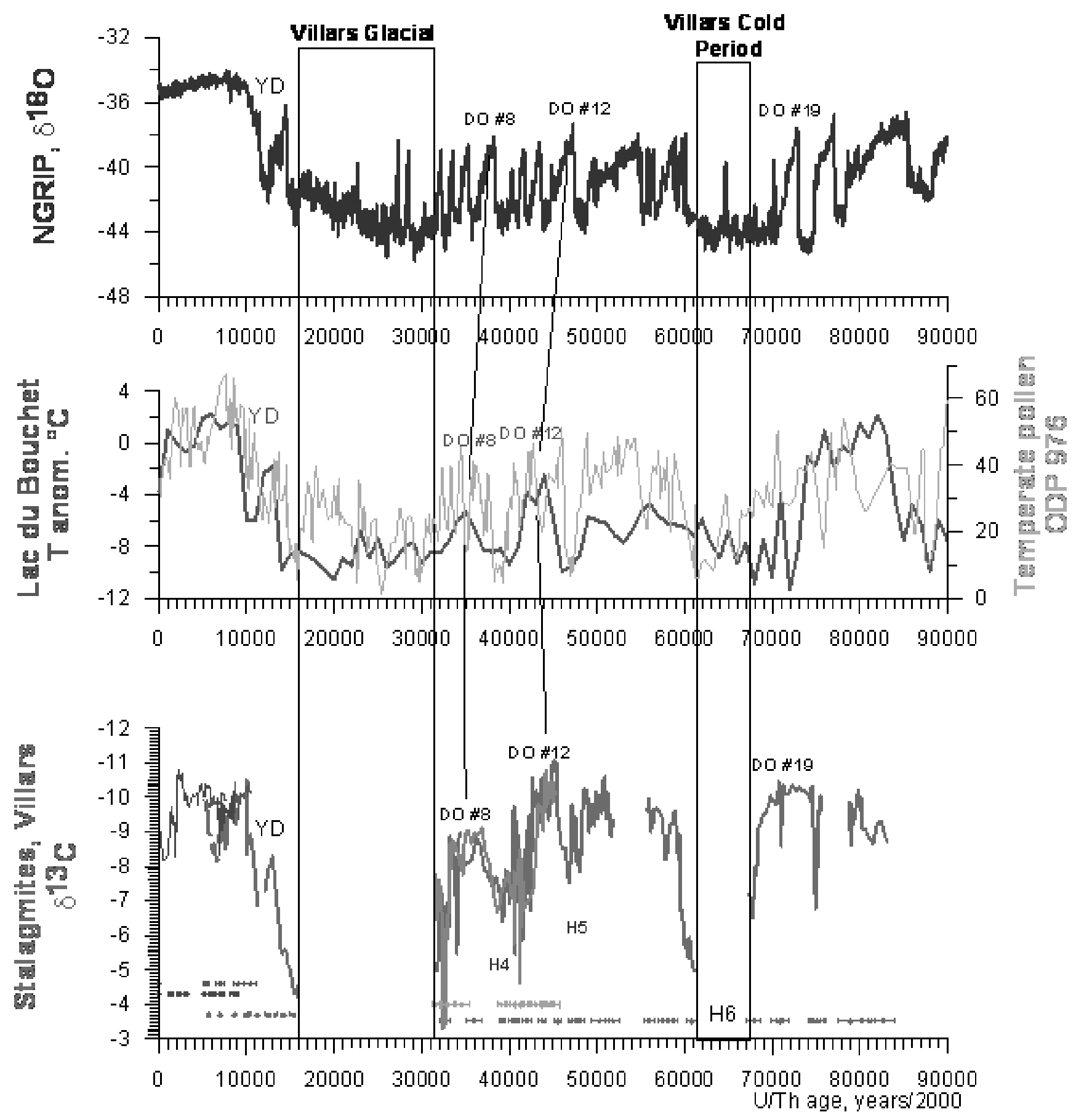

Fig. 25. The last 90 ka recorded in the Villars cave $\square 13 \mathrm{C}$ stalagmites (from Genty et al., 2003; 2006 and unpublished). Comparison with: (top) Greenland ice core record (NGRIP members, 2004) and (middle) pollen records from the Le Bouchet Lake (pollen reconstructed annual mean temperature, thick line; de Beaulieu et al., 1992: Guiot et al. 1993) and marine core ODP 976 (\% of temperate pollen grains, thin line; CombourieuNebout et al., 2002). DO = Dansgaard-Oeschger events; YD = Younger-Dryas. 
Thanks to these records, a specific climatic pattern was drawn for the SW-France area which is summarized by :

1) a well pronounced warm event during MIS 3, between $\sim 46.6 \mathrm{ka}$ and $\sim 43 \mathrm{ka}$, which is associated with the DO\#12 (replicated on 3 stalagmites) and where the $\delta^{13} \mathrm{C}$ is as low as present day and where the growth rate is high;

2) two extremely cold periods that prevent speleothem growth likely due to a permafrost : between 67.4 and 61 ka "the Villars Cold Phase" and between 31.5 and 16.5 ka "the Villars Glacial";

3) a general climatic cooling trend from the warm optimum of the DO\#12 at 45.5 ka until the synchronous stop of the stalagmites at $\sim 31.5 \mathrm{ka}$.

This pattern shows similarities with the Greenland climatic changes (large amplitude DO events), but it also displays differences (i.e. MIS3 cooling trend) that are due to regional differences facing global climatic variations. More progress is needed to quantify the climatic changes which can be reached using fluid inclusions and $\Delta 47$ techniques (Daeron et al., 2008; Ghosh et al., 2006; Vonhof et al., 2006). This will be of first importance to better understand, not only the climatic forcings by comparing with other archives and numerical models, but also changes observed in the remains of ancient human cultures that are numerous in this area.

\section{ACKNOWLEDGEMENTS}

This work was funded by the INSU/CNRS program ECLIPSE and partly by ANR PICC program and Leverhulme Grants. We want to thank the cave owners Hubert and Marie-Paule Versaveau who have given us their confidence for 15 years. We are grateful to Thierry Baritaud who helped us in sampling and exploring Villars Cave, to Brigitte and Gilles Delluc for their precious information about archeological observations and to Pierre Vidal, one of the Villars Cave discovers, for his advice. We thank O. Mestre from Météo France for his help in obtaining meteorological data.

We thank Sandra Van Exter and the Maison des Sciences de 1'Eau (Hydrosciences, Montpellier) for the dripping water chemistry measurements.

\section{REFERENCES}

Baker A. \& Genty D., 1998 - Environmental pressures on conserving cave speleothems: effects of changing surface land use and increased cave tourism. Journal of Environmental Management, 53: 165-175.

Baker A. \& Genty D., 1999 - Fluorescence wavelength and intensity variations of cave waters. Journal of Hydrology, 217: 19-34.

Baker A., Genty D., Dreybrodt W., Barnes W. L., Mockler N. J. \& Grapes J., 1998 - Testing theoretically predicted stalagmite growth rate with recent annually laminated samples: Implications for past stalagmite deposition. Geochimica et Cosmochimica Acta, 62: 393-404.

Baker A., Genty D. \& Fairchild I., 2000 - Hydrological characterisation of stalagmite dripwaters at Grotte de Villars, Dordogne, by the analysis of inorganic species and luminescent organic matter. Hydrology and Earth System Sciences, 4: 439-449.
Baker A., Ito E., Smart P. L. \& McEwan R. F., 1997 Elevated and variable values of $13 \mathrm{C}$ in speleothems in a British cave system. Chemical Geology, 136 (3-4): 263-270.

Baldini J. U. L., McDermott F., Baker A., Baldini L. M., Mattey D. P. \& Railsback L. B., 2005 - Biomass effects on stalagmite growth and isotope ratios: A 20th century analogue from Wiltshire, England. Earth and Planetary Science Letters, 240: 486-494.

Bourges F., Mangin A. \& d'Hulst D., 2001 - Carbon dioxide in karst cavity atmosphere dynamics: the example of the Aven d'Orgnac (Ardeche). Comptes Rendus de L'Academie des Sciences, Serie II, Fascicule A-Sciences de la Terre et des Planetes, 333: 685-692.

Collister C. \& Mattey D., 2008 - Controls on water drop volume at speleothem drip sites : an experimental study. Journal of Hydrology, 358 (3-4): 259-267.

Combourieu Nebout N., Turon J.L., Zahn R., Capotondi L., Londeix L. \& Pahnke K., 2002 - Enhanced aridity and atmospheric high-pressure stability over the western Mediterranean during the North Atlantic cold events of the past $50 \mathrm{ky}$, Geology 30: 863-866.

Craig H., 1965 - Stable Isotopes in Oceanographic Studies and Palaeotemperatures. In: Tongiorgi E. (Ed.), Consiglio Nazionale delle Ricerche Laboratorio di Geologia Nucleare., Pisa: 161-182.

Daeron M., Guo W., Eiler J. M., Genty D., Wainer K., Affek H., Vonhof H. \& Blamart D., 2008 - Quantitative speleothermometry? Using clumped-isotopes measurements to correct for kinetic isotope fractionations induced by $\mathrm{CO}_{2}$ degassing. In European Geosciences Union, Vienna, Austria.

de Beaulieu J. L. \& Reille M., 1992 - Long Pleistocene pollen sequences from the Velay Plateau (Massif Central, France). Veget. Hist. Archaeobot., 1: 233242

Delluc B. \& Delluc G., 1974 - La grotte ornée de Villars. Gallia Préhistoire, 17: 1-67.

Drake J. J., 1983 - The effect of geomorphology and seasonality on the chemistry of carbonate groundwater. Journal of Hydrology, 61: 223-236.

Dreybrodt W., 1988 - Processes in Karst Systems. Springer Verlag, Berlin, 288 p.

Fairchild I. J., Borsato A., Tooth A. F., Frisia S., Hawkesworth C. J., Huang Y. M., McDermott F. \& Spiro B., 2000 - Controls on trace element (Sr-Mg) compositions of carbonate cave waters: implications for speleothem climatic records. Chemical Geology, 166: 255-269.

Fairchild I. J., Smith C. L., Baker A., Fuller L., Spotl C., Mattey D., McDermott F. \& Eimp, 2006 Modification and preservation of environmental signals in speleothems. Earth-Science Reviews, 75: 105-153.

Fantidis J. \& Ehhalt D. H., 1970 - Variations of the carbon and oxygen isotopic composition in stalagmites and stalactites: evidence of non-equilibrium isotopic fractionation. Earth and Planetary Science Letters, 10: $136-144$.

Fenelon P., 1951 - Le Périgord - Etude Morphologique. Lahure, Paris.

Ford D. C. \& Williams P., 1992 - Karst Geomorphology and Hydrology. Chapmann \& Hall. London. 601 p. 
Fornaca-Rinaldi G., Panichi C. \& Tongiorgi E., 1968 Some causes of the variation of the isotopic composition of carbon and oxygen in cave concretions. Earth and Planetary Science Letters, 4: 321-324.

Friedman I. \& O'Neil J.R., 1977 - Compilation of stable isotopefractionation factors of geochemical interest. In: Fleischer (Ed.),Data of Geochemistry, 6th Ed. Geological Survey Professional.Paper 440-KK

Genty D., 2003 - Ice Ages in Perigord. In: Genty D. (Ed.): Karst Record 3, 66 p. CEA, Montpellier.

Genty D. \& Baker A., 2008 - Radiocarbon in speleothems. Radiocarbon, in progress.

Genty D., Baker A. \& Barnes W., 1997 - Comparaison entre les lamines luminescentes et les lamines visibles annuelles de stalagmites. Comptes Rendus de l'Académie des Sciences de Paris, Sciences de la terre et des planètes, 325: 193-200.

Genty D., Baker A., Massault M., Proctor C., Gilmour M., Pons-Branchu E. \& Hamelin B., 2001a - Dead carbon in stalagmites: Carbonate bedrock paleodissolution vs. ageing of soil organic matter. Implication for ${ }^{13} \mathrm{C}$ variation in speleothems. Geochimica et Cosmochimica Acta, 65: 3443-3457.

Genty D., Baker A. \& Vokal B., 2001b - Intra- and interannual growth rate of modern stalagmites. Chemical Geology, 176: 191-212.

Genty D., Blamart D., Ghaleb B., Plagnes V., Causse C., Bakalowicz M., Zouari K., Chkir N., Hellstrom J., Wainer K. \& Bourges F., 2006 - Timing and dynamics of the last deglaciation from European and North African delta $C$-13 stalagmite profiles - comparison with Chinese and South Hemisphere stalagmites. Quaternary Science Reviews, 25: 2118-2142.

Genty D., Blamart D., Ouahdi R., Gilmour M., Baker A., Jouzel J. \& Van-Exter S., 2003 - Precise dating of Dansgaard-Oeschger climate oscillations in western Europe from stalagmite data. Nature, 421: 833-837.

Genty D., Combourieu Nebout N., Hatté C., Blamart D., Ghaleb B. \& Isabello L., 2005 - Rapid climatic changes of the last $90 \mathrm{kyr}$ recorded on the european continent. Comptes Rendus de l'Académie des Sciences de Paris, 337: 970-982.

Genty D. \& Deflandre G., 1998 - Drip flow variations under a stalactite of the Père Noël cave (Belgium). Evidence of seasonal variations and air pressure constraints. Journal of Hydrology, 211: 208-232.

Genty D., Diot M. F. \& O’Y1 W., 2001c - Sources of pollen in stalactite drip water in two caves in southwest France. Cave and Karst Science, 28: 59-66.

Genty D. \& Massault M., 1997 - Bomb ${ }^{14} \mathrm{C}$ recorded in laminated speleothems : calculation of dead carbon proportion. Radiocarbon, 39: 33-48.

Genty D. \& Massault M., 1999 - Carbon transfer dynamics from bomb ${ }^{14} \mathrm{C}$ and $\delta^{13} \mathrm{C}$ time series of a laminated stalagmite from SW France - Modelling and comparison with other stalagmite records. Geochimica et Cosmochimica Acta, 63: 1537-1548.

Genty D., Massault M., Gilmour M., Baker A., Verheyden S. \& Keppens E., 1999 - Calculation of past dead carbon proportion and variability by the comparison of AMS ${ }^{14} \mathrm{C}$ and TIMS U/Th ages on two Holocene stalagmites. Radiocarbon, 41: 251-270.
Genty D., Plagnes V., Causse C., Cattani O., Stievenard M., Falourd S., Blamart D., Ouahdi R. \& Van-Exter S., 2002 - Fossil water in large stalagmite voids as a tool for paleoprecipitation stable isotope composition reconstitution and paleotemperature calculation. Chemical Geology, 184: 83-95.

Ghosh P., Adkins J., Affek H., Balta B., Guo W. F., Schauble E. A., Schrag D. \& Eller J. M., 2006 - C-13O-18 bonds in carbonate minerals: A new kind of paleothermometer. Geochimica et Cosmochimica Acta, 70: 1439-1456.

Glory A. \& Pierret B., 1960 - La grotte ornée de Villars. Bulletin de la Société Préhistorique Française, 62: 355-361.

Guiot J., de Beaulieu J.-L., Cheddadi R., David F., Ponel P. \& Reille M., 1993 - The climate in western Europe during the last glacial/interglacial cycle derived from pollen and insect remains. Palaeogeography, Palaeoclimatology, Palaeoecology 103: 73-94.

Huang H. M., Fairchild I. J., Borsato A., Frisia S., Cassidy N. J., McDermott F. \& Hawkesworth C. J., 2001 - Seasonal variations in $\mathrm{Sr}, \mathrm{Mg}$ and $\mathrm{P}$ in modern speleothems (Grotta di Ernesto, Italy). Chemical Geology, 175: 429-448.

Kim S.-T. \& O'Neil J. R., 1997 - Equilibrium and nonequilibrium oxygen isotope effect in synthetic carbonates. Geochimica et Cosmochimica Acta, 61: 3461-3475.

Lacelle D., Lauriol B. \& Clark I. D., 2004 - Seasonal isotopic imprint in moonmilk from Caverne de l'Ours (Quebec, Canada): implications for climatic reconstruction. Canadian Journal of Earth Sciences, 41: 1411-1423.

Leng M. J. \& Marshall, J. D. 2004 - Palaeoclimate interpretation of stable isotope data from lake sediment archives. Quaternary Science Reviews, 23: 811-831.

Mickler P. J., Stern L. A. \& Banner J. L., 2006 Large kinetic isotope effects in modern speleothems. Geological Society of America Bulletin, 118: 65-81.

O’Neil J. R., Clayton R. N. \& Mayeda T. K., 1969 - Oxygen isotope fractionation in divalent metal carbonates. Journal of Chemical Physics, 51: 5547-5558.

Rozanski K., Araguas-Araguas L. \& Gonfiantini R., 1993 - Isotopic Patterns in Modern Global Precipitation, in Climate Change in Continental Isotopic Records. Geophysical Monograph, 78: 1-36.

Sturm K., Hoffmann G., Langmann B. \& Stichler W., 2005 - Simulation of delta O-18 in precipitation by the regional circulation model REMOiso. Hydrological Processes, 19: 3425-3444.

Vonhof H. B., van Breukelen M. R., Postma O., Rowe P. J., Atkinson T. C. \& Kroon D., 2006 - A continuous-flow crushing device for on-line delta $\mathrm{H}$-2 analysis of fluid inclusion water in speleothems. Rapid Communications in Mass Spectrometry, 20: 2553-2558.

Wainer K., Genty D., Blamart D., Caillon N., Ghaleb B., Bar-Matthews M., Plagnes V. \& Quinif Y., 2007 - High resolution isotopic and trace element record of the Last Interglacial from a flowstone from the Villars Cave (SWFrance). In: "EGU General Assembly." Geophysical Research Abstracts, 9: Abstract n 01327, Vienna. 